American University Washington College of Law

Digital Commons @ American University Washington College of

Law

Joint PIJIP/TLS Research Paper Series

$12-6-2011$

\title{
Public Interest Analysis of the US TPP Proposal for an IP Chapter
}

\author{
Sean Flynn \\ American University Washington College of Law, sflynn@wcl.american.edu \\ Margot E. Kaminski \\ Yale Law School, margot.kaminski@gmail.com \\ Brook K. Baker \\ Northeastern University, b.baker@neu.edu \\ Jimmy H. Koo
}

Follow this and additional works at: https://digitalcommons.wcl.american.edu/research

Part of the Intellectual Property Law Commons, and the International Trade Law Commons

\section{Recommended Citation}

Flynn, Sean; Kaminski, Margot E.; Baker, Brook K.; and Koo, Jimmy H., "Public Interest Analysis of the US TPP Proposal for an IP Chapter" (2011). Joint PIJIP/TLS Research Paper Series. 21.

https://digitalcommons.wcl.american.edu/research/21

This Article is brought to you for free and open access by the Program on Information Justice and Intellectual Property and Technology, Law, \& Security Program at Digital Commons @ American University Washington College of Law. It has been accepted for inclusion in Joint PIJIP/TLS Research Paper Series by an authorized administrator of Digital Commons @ American University Washington College of Law. For more information, please contact DCRepository@wcl.american.edu. 
Program on Information Justice and Intellectual Property

American University Washington College of Law

\section{Public Interest Analysis of the US TPP Proposal for an IP Chapter}

Draft Version 1.3

December 6, 2011

\section{Sean Flynn}

American University Washington College of Law, Associate Director, PIJIP

Margot Kaminski

Yale Law School, Executive Director, Information Society Project

Brook Baker

Northeastern University School of Law, Program on Human Rights and the Global Economy

Jimmy Koo

American University Washington College of Law, Fellow, PIJIP 


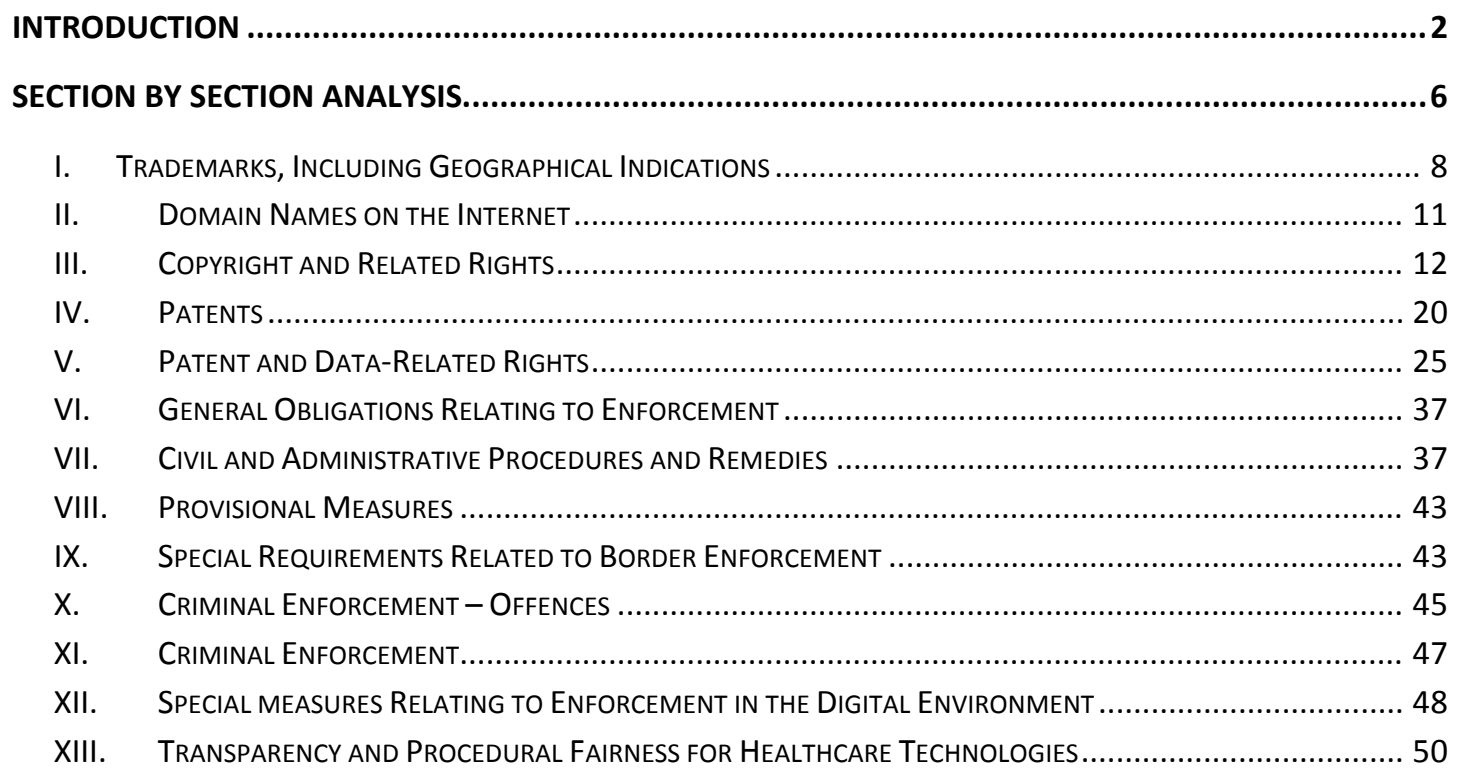

\section{INTRODUCTION}

This briefing paper provides preliminary analysis of two leaked U.S. proposals for an intellectual property chapter in the Trans Pacific Partnership (TPP) agreement and of a related proposed chapter regulating pharmaceutical reimbursement programs. ${ }^{1}$

The U.S. proposals, if adopted, would upset the current international framework balancing the minimum standards for exclusive rights for media and technology owners, on the one hand, and the access rights of the public, competitors, innovators and creators, on the other. The proposed U.S. IP chapter greatly exceeds the imperfect, but more balanced provisions codified in the 1994 WTO Trade-Related Aspects of Intellectual Property Rights Agreement [hereinafter TRIPS].2 The

1 Trans-Pacific Partnership, Intellectual Property Rights Chapter February Draft [hereinafter TPP], available at http://keionline.org/sites/default/files/tpp-10feb2011-us-text-ipr-chapter.pdf; Trans-Pacific Partnership, Intellectual Property Rights Chapter September 2011 Draft (Selected Provisions) [hereinafter TPP-2], available at http://www.citizenstrade.org/ctc/wpcontent/uploads/2011/10/TransPacificIP1.pdf; Transparency Chapter - Annex on Transparency and Procedural Fairness for Healthcare Technologies June 22, 2011 Draft [hereinafter Transparency Chapter] available at http://www.citizenstrade.org/ctc/wpcontent/uploads/2011/10/TransPacificTransparency.pdf.

${ }^{2}$ Agreement on Trade-Related Aspects of Intellectual Property Rights, Art. 15, Apr. 15, 1994, Marrakesh Agreement Establishing the World Trade Organization, Annex 1C, Legal Instruments-Results of the Uruguay Round, 1869 U.N.T.S. 299 [hereinafter TRIPS]. 
proposals are primarily based on, and frequently go beyond, the maximalist and controversial standards of the Korea-U.S. Free Trade Agreement (KORUS) ${ }^{3}$ and the Anti-Counterfeiting Trade Agreement (ACTA), ${ }^{4}$ neither of which was subject to an open and transparent negotiation process. The provisions of the TPP proposals are inconsistent with the current laws in every TPP member country for which public analysis is available, ${ }^{5}$ including the U.S. itself. ${ }^{6}$ The proposal is also a new step for U.S. international policy, abandoning the development-oriented flexibilities on access to medicines expressed in the 2007 New Trade Deal between Congress and the Bush Administration. ${ }^{7}$

The U.S. combined proposals are particularly inappropriate for developing countries where the risks and effects of exclusionary pricing by foreign monopolists are most acute. ${ }^{8}$ The U.S. TPP proposals are the latest manifestation of its maximalist agenda in international intellectual property, ${ }^{9}$ which stands in stark

${ }^{3}$ Free Trade Agreement between the United States of America and the Republic of Korea, U.S.-S. Korea, June 30, 2007 [hereinafter KORUS], available at http://www.ustr.gov/Trade_Agreements/Bilateral/Republic_of_Korea_ FTA/Final_Text/Section_Index.html.

${ }^{4}$ Anti-Counterfeiting Trade Agreement, Dec. 3, 2010 [hereinafter ACTA], available at http://www.dfat.gov.au/trade/acta/Final-ACTA-text-following-legal-verification.pdf.

${ }^{5}$ See Public Citizen, Comparative Analyses of the U.S. Trans-Pacific Partnership IP Proposals and Existing Laws in Participating Countries http://www.citizen.org/Trans-pacific-FTA-charts (comparing the leaked TPP IP chapter to the laws of Vietnam, Malaysia, Australia, Peru).

${ }^{6}$ See Jodie Griffin, Inconsistencies Between the Trans-Pacific Partnership (TPP) Agreement and US Law, Public Knowledge, www.publicknowledge.org/files/TPP\%20Analysis.pdf

${ }^{7}$ New Trade Policy for America, House Committee on Ways and Means, [hereinafter New Trade Policy], available at http://waysandmeans.house.gov/media/pdf/NewTradePolicy.pdf. An extended summary of the New Trade Policy provisions on patents/IPRs and access to medicines can be found in Mac Dressler, American Trade Politics in 2007: Building Bipartisan Compromise, Policy Brief, Peterson Institute for International Economics 25-26 (May 2007) available at http://www.iie.com/publications/pb/pb07-5.pdf. The New Trade Deal was included in revisions to the U.S.-Peru Trade Promotion Agreement and U.S.-Colombia Free Trade Agreement IP Chapters. U.S.-Peru Trade Promotion Agreement, Chapter 16 Intellectual Property Rights (revised June 29, 2007) available athttp://www.ustr.gov/webfm_send/1031; U.S.-Colombia Free Trade Agreement, Chapter 16 Intellectual Property Rights, available at http://www.ustr.gov/webfm send/1336. See Public Citizen Media Alert: On Access to Medicines, Obama Trade Pact Proposal Appears Set to Undo Bush-Era Improvements. Public Citizen, 13 September 2011.

${ }^{8}$ See Sean Flynn, Aidan Hollis \& Michael Palmedo, An Economic Argument for Open Access to Medicine Patents in Developing Countries, 37 J.L. Med. \& Ethics 184 (2009) (explaining that intellectual monopolies in developing countries with high income inequality predictably lead to more exclusionary pricing practices than in wealthier countries).

${ }^{9}$ See Susan Sell, The Global IP Upward Ratchet, Anti-Counterfeiting and Piracy Enforcement Efforts: The State of Play, PIJIP Working Paper No. 15, at 3, available at http://digitalcommons.wcl.american.edu/research/; see also Analysis of the Leaked New Zealand Paper on the Trans-Pacific Partnership Agreement and Intellectual Property, THIRD WORLD NETWORK \& 
contrast to the "development agenda"10 being debated in more open, transparent multilateral forums. ${ }^{11}$ Substantively, the development agenda is focused on maximizing differentiation and flexibility in protection and enforcement, while globalizing a set of mandatory minimum limitations and exceptions - including for persons with visual impairments, for libraries, for educational uses and to promote access to needed medicines and technologies. A summary of some the key differences between the maximalist agenda and the development agenda are included in the table below.

Public Citizen (Dec. 3, 2010), available at http://www.citizen.org/documents/analysisoftheleakednewzealandpaper.pdf (warning that "[a]ny enforcement measures adopted in the TPPA would have to depart considerably from the global IP Enforcement agenda that has emerged in recent years, or would be likely to undermine the culture of flexibility and context in intellectual property rules.").

10 See World Intellectual Prop. Org., Development Agenda For WIPO (2007), available at http://www.wipo.int/ip-development/en/agenda/. For a declaration of principles of hundreds of intellectual property academics and experts calling for a policy agenda more supportive of the public interest, see The Global Cong. on Intellectual Prop. And the Pub. Interest, Washington Declaration on InTElLeCtuAl Property AND the PUblic InTEREST, available at http://infojustice.org/washingtondeclaration. See generally, Peter Yu, A Tale of Two Development Agendas, 35 Ohio N.U. L. Rev. 465 (2009) (comparing present and past intellectual property policy agendas led by developing countries).

${ }^{11}$ See Jeremy Malcolm, Public Interest Representation in Global IP Policy Institutions 19-21 (PIJIP, Research Paper No. 6, 2010), available at http://digitalcommons.wcl.american.edu/cgi/viewcontent.cgi?article=1006\&context=research. 


\section{MAXIMALIST AGENDA \\ PROCESS: Plurilateral, unilateral; closed processes \\ e.g. ACTA, TPP, Special 301 Watch List. \\ SCOPE OF RIGHTS: One-size-fits-all rights; voluntary limitations and exceptions \\ e.g. Expansions of trademark to non-visual identifiers, lengthening copyright terms, extension of patents to new uses of known products. \\ decreased evidentiary standards.}

\section{POSITIVE/DEVELOPMENT AGENDA}

Multilateral; open processes

e.g. WIPO, WTO, WHO, UN.
Differentiation in scope and enforcement of IPRs and mandatory, minimum limitations and exceptions

e.g. India sec. 3(d) (banning new use patents with no increase in efficacy), WIPO proposed treaty for Visually Impaired Persons.

Retain private burden of enforcement; maximize due process for accused.

e.g. maintain enforcement processes in judicial forums initiated by rights holders.
LIABILITY: shift criminal and civil liability to end-users and intermediaries.

e.g. redefine "commercial scale" to "indirect economic advantage"; graduated response obligations on internet; ISP and intermediary liability; information disclosure mandates.
Target large commercial entities, high liability thresholds.

e.g. China's qualitative (for profit) and quantitative thresholds for criminal counterfeiting, upheld in U.SChina: Measures Affecting the Protection and Enforcement of Intellectual Property Rights (WTO/DS362).

DAMAGES: “Deterrent" level penalties set through statutory and presumed damages.

e.g. Tenenbaum case, $\$ 675,000$ in damages for uploading 30 songs to a sharing cite. Limewire damage request -- $\$ 75$ trillion.

\section{Damages adequate to compensate rights holder.}

e.g. TRIPS Art. 31(k) permitting zero royalty compulsory licenses in cases of anticompetitive conduct..

The U.S. TPP proposal includes a Transparency/Pharmaceutical Pricing Chapter that has never been proposed for any developing country. The proposal extends international minimum standards for domestic regulation beyond intellectual property and into health policy itself. The chapter advances proposals that would undermine countries' policy space to adopt and enforce therapeutic formularies, reimbursement policies and other price moderating mechanisms within public health systems. The U.S. succeeded in obtaining similar chapters in trade agreements with Australia and Korea, two OECD countries. These standards are 
inappropriate for developing countries. And in many ways the TPP proposal goes further than these controversial agreements. Ironically, the substantive provisions in the proposal (and included in the Australia and Korea agreements) are not followed by U.S. pharmaceutical reimbursement programs, most notably Medicaid.

No country, including the U.S., has an interest in ceding this much policy flexibility to an international agreement, particularly through an international agreement subject to such a limited public process. As with the recently concluded and highly criticized ACTA, the TPP proposal seeks to put in place a major and consequential shift in international standards for domestic regulation with scant public process, on the one side, and a highly structured and consultative relationship with a limited range of commercial interests on the other. This process denies TPP negotiators access to a full range of views and analysis that deliberation in a public forum would attract. A better process would be to reject the U.S. TPP proposal in its entirety and limit any intellectual property, internet and pharmaceutical regulations to standards already adopted through an open and transparent multilateral process. ${ }^{12}$

\section{Section by Section Analysis}

This part summarizes the many ways in which the U.S. proposal for the IP chapter of TPP implements and exceeds the TRIPS-plus provisions of ACTA, KORUS, and U.S. law. The U.S. TPP proposal would:

- Expand the scope of trademark protection to sounds, scents and "well known" marks that are not well known in the local territory, while diluting geographic indication protections - all in direct contravention to flexibilities in TRIPS allowing policy choice in these areas.

- Adopt provisions on internet domain names that would preempt expert discussions on this very topic in ICANN's multi-stakeholder forum.

- Dramatically expand international obligations on the length and scope of copyrights, including extending protection to "temporary" storage on the

12 See Washington Declaration on Intellectual Property and the Public Interest. Washington D.C., August 2011. Available at: http://infojustice.org/washington-declaration ("International intellectual property policy affects a broad range of interests within society, not just those of rights holders. Thus, intellectual property policy making should be conducted through mechanisms of transparency and openness that encourage broad public participation."). Somewhat ironically, the closed-door process for policy making being used in TPP violates the standards included in the leaked chapters on "Regulatory Coherence" and "Transparency and Procedural Fairness for Healthcare Technologies," for example. See leaked text available at http://www.citizenstrade.org/ctc/blog/2011/10/22/leaked-trans-pacific-fta-texts-reveal-u-sundermining-access-to-medicine/ 
internet and doubling the mandatory minimum length of many copyright terms.

- Require the adoption of a highly controversial form of anti-circumvention liability that would punish circumvention of digital locks regardless of intent.

- Expand the international mandatory scope of patentability to include monopoly protections for (1) new uses or forms of known products, and (2) for plants, animals, and medical procedures. The first set of standards is in direct conflict with the anti-evergreening provisions recently enacted in India and Philippines. The second set of standards is direct conflict with the flexibility in Section 27.3 of TRIPS.

- Alter the international legislative framework on patent applications, oppositions, revocation, required disclosure and utility standards to make patents easier to obtain, harder to challenge or revoke, and less beneficial to technology transfer.

- Abandon the access to medicines flexibilities of the 2007 New Trade Deal and the U.S.-Peru Free Trade Agreement and put in their place a set of patent extensions and registration monopolies for branded drugs conditioned only on compliance with an "access window" defined without regard to affordability. These provisions will predictably lead to higher prices and lower availability of pharmaceutical products, especially in developing countries.

- Implement the most draconian enforcement provisions of ACTA and U.S. law to shift the cost and burden of enforcing private intellectual property rights enforcement to the government, internet and other intermediaries and consumers, while reducing due process and administrative justice rights in their implementation.

- Export a new and controversial set of restrictions on the efficacy of price negotiations in pharmaceutical reimbursement programs that have never before been proposed for developing countries and that are not adhered to in the U.S. itself.

Each of these points is explained more fully below. 


\section{TRADEMARKS, INCLUDING GEOGRAPHICAL INDICATIONS}

\section{A. Art. 2.1 - Protectable Trademark Subject Matter}

TPP Art. $2.1^{13}$ would expand the mandatory scope of trademark protection by deleting the TRIPS Art. 15 flexibility that a country may require "as a condition of registration, that a sign be visually perceptible." 14 It additionally prohibits a Party from denying "registration of a trademark solely on the grounds that the sign of which it is composed is a sound or a scent."

This provision is identical to Art. 18.2.1 of the U.S.-South Korea Free Trade Agreement (KORUS) ${ }^{15}$ and incorporates the scope of trademark subject matter under $\S 45$ of the U.S. Lanham Act. The latter has been interpreted to include, inter alia, colors per se, 2D/3D designs, motion marks, sound (NBC's three chimes ${ }^{16}$ ), scent (plumeria blossoms on sewing thread ${ }^{17}$ ), and non-visual marks. ${ }^{18}$

The risk of the provision is that, by removing the requirement that a trademark be a visual mark, it will carry other countries along the U.S. path of transforming trademark law into a species of general (and perpetual) monopoly protection, including for products that cannot obtain copyright or patent protection. ${ }^{19}$

\section{B. FN 4 - Definition of "Geographical Indications"}

While the U.S. proposal expands the scope of trademark protection, it restricts the operation of geographical indications as a field of protection distinguishable from trademark. The first encroachment on this field is contained in the definition in

${ }^{13}$ As noted above, throughout this analysis the U.S. TPP proposal is referred to merely as "TPP." This reference therefore refers to Art. 2.1 of the U.S. TPP proposal as leaked to the public in February 2011, supra note 1.

${ }^{14}$ Agreement on Trade-Related Aspects of Intellectual Property Rights, Art. 15, Apr. 15, 1994, Marrakesh Agreement Establishing the World Trade Organization, Annex 1C, Legal Instruments-Results of the Uruguay Round, 1869 U.N.T.S. 299 [hereinafter TRIPS].

${ }^{15}$ Free Trade Agreement between the United States of America and the Republic of Korea, U.S.-S. Korea, June 30, 2007 [hereinafter KORUS], available at http://www.ustr.gov/Trade_Agreements/Bilateral/Republic_of_Korea_ FTA/Final_Text/Section_Index.html.

${ }^{16}$ NBC's 3-Note Chime, available at http://www.uspto.gov/web/offices/ac/ahrpa/opa/kids/soundex/72349496.mp3.

${ }^{17}$ In re Clarke, 17 U.S.P.Q.2D (BNA) 1238, 1240 (TTAB 1990) (allowing registration of plumeria blossom scented sewing thread).

${ }^{18}$ U.S. PATENT \& TRADEMARK OfFICE, U.S. TRADEMARK LAW - RULES OF PRACTICE \& FEDERAL STATUTES $\S 2.25(\mathrm{e})$ (explaining that "[a]n applicant is not required to submit a drawing if the mark consists only of a sound, a scent, or other completely non-visual matter.”).

${ }^{19}$ See Glynn S. Lunney, Trademark Monopolies, 48 EMORY L.J. 367 (1999) (criticizing the shift in U.S. trademark law away from a consumer protection motivation). 
footnote 4, but continues in other sections as described below. Footnote 4 broadens the TRIPS Art. 22.1 definition of a geographic indicator (GI),20 requiring the protection of a "sign or combination of signs ... in any form whatsoever." 21 The non-exhaustive list of examples of "sign or combination of signs" contains many elements similar to protectable trademarks, such as personal names, letters, numerals, figurative elements, and colors, including color per se..$^{22}$

\section{Art. 2.4 - Identical/Similar Signs and Identical/Similar/Related Goods or Services}

TPP Art. 2.4 expands the scope of trademark protection in TRIPS Art. 16.1 from prohibiting the use of identical or similar signs "for identical or similar goods or services" to a prohibition of the use of similar signs "for goods and services that are related to those goods or services in respect of which the owner's trademark is registered." 23 The impact of this change in standards is unclear. Presumably a good could be "related to" the trademarked good without being identical or similar to it. This raises the possibility that trademark will be used to cut off uses of marks that are not confusing consumers or competing with the branded product at all - making trademark a new form of monopoly protection rather than a consumer protection norm..$^{24}$

Unlike TRIPS, the U.S. TPP proposal includes GI's within the purview of this provision. This is another instance of the apparent aim of the proposal to reduce GI protection to that of trademark.

\section{Arts. 2.6, 2.7, and FN 5 - Well-Known Marks \& the "Use In Commerce" Standard}

TPP Art. 2.6 exports the "use in commerce" standard of trademark protection in the U.S. The "use in commerce" standard in $\S 1$ of the Lanham Act provides the fundamental basis for trademark protection in the United States. ${ }^{25}$ Unlike in other

${ }^{20}$ TRIPS Art. 22.1 (defining 'geographical indications' as "indications which identify a good as originating in the territory of a Member, or a region or locality in that territory, where a given quality, reputation or other characteristic of the good is essentially attributable to its geographical origin.").

${ }^{21}$ TPP FN4.

${ }^{22}$ Id.

${ }^{23}$ TPP Art. 2.4 (emphasis added). Compare to TRIPS Art. 16.1 (stating that "[t]he owner of a registered trademark shall have the exclusive right to prevent all third parties not having the owner's consent from using in the course of trade identical or similar signs for goods or services which are identical or similar to those in respect of which the trademark is registered where such use would result in a likelihood of confusion. In case of the use of an identical sign for identical goods or services, a likelihood of confusion shall be presumed.").

${ }^{24}$ See Mark McKenna, Testing Modern Trademark Law's Theory of Harm, 95 IowA L. REv. 63 (2009).

${ }^{25}$ Lanham Act, 15 U.S.C. § 1051 (2005); see also U.S. PATENT \& TRADEMARK OfFICE, All About TRADEMARKS, available at http://www.uspto.gov/smallbusiness/trademarks/registering.html 
jurisdictions, this standard does not require registration as a condition precedent for trademark protection. ${ }^{26}$

In defining a "well-known mark", TPP FN 5 twists the language of TRIPS Art. 16.2 , which requires that, "[i]n determining whether a trademark is well-known, Members shall take account of the knowledge of the trademark in the relevant sector of the public." The TRIPS provision is open ended. Members may also take into consideration other factors. The TPP proposal turns the TRIPS language into a closed list, banning any other consideration than whether the reputation of the wellknown in "sector of the public that normally deals with the relevant goods or services."

\section{E. Arts. 2.15, 2.18 - Refusing Protection or Recognition of GI}

Articles 2.15 and 2.18 continue the trend of refusing to fully recognize geographical indicators at the TRIPS standard.

\section{Art. 2.15}

TPP Art. 2.15 makes GIs a subsidiary doctrine to trademark. TRIPS Art. 22 protects GIs by requiring parties to prevent designation of geographical origin where such designation "misleads the public as to the true place of origin." 27 TPP Art. 2.15 changes this focus on geographic origin confusion by prohibiting the use of a GI that is "likely to cause confusion with a trademark." The provision thus alters the fundamental focus of GI protection from the protection of goods from a specific place of origin to the protection of goods with specific trademark or indication, giving priority to trademarks over GIs in the case of conflict between the two.

\section{Art. 2.18}

Article 2.18 defines a generic GI in a way that would allow one country's generic use of a term to defeat a claim of a GI that is protected in another country. TPP Art. 2.15(a)(iv) recognizes that generic terms should not be protected as GIs. TPP Art. 2.18 notes that "a term is generic if it is the term customary in common language as the common name for the goods or services associated with the trademark or geographical indication." 28 This definition is similar to TRIPS Art. $24.6,{ }^{29}$ but omits

(explaining the required steps for trademark protection in the United States).

${ }^{26}$ Trademark Protection in France, EURIMARK,

http://www.eurimark.com/index.php/de/nationales-recht/45-france/135-french-trademarks (explaining that " $[\mathrm{u}] \mathrm{se}$ of a Trademark in France does not confer any rights without a trademark registration to support it.").

${ }^{27}$ TRIPS Art. 22.

${ }^{28}$ TPP Art. 2.18.

29 "Nothing in this Section shall require a Member to apply its provisions in respect of a 
the restriction that the term should have become generic "in the territory of the Member." 30 This appears to open the possibility that a GI term could be considered generic in one country (e.g. Peru) because it has become generic in another member country (e.g. U.S.).

\section{F. Art. 2.22 - GI Use for Goods and Services Not From the True Place of Origin}

Continuing the proposal's recognition of trademarks as superior to GI protection, TPP Art. 2.22 permits the use or registration of signs or indications that reference a geographical area even though it is not the true place or origin of the goods or services.

\section{DOMAIN NAMES ON THE INTERNET}

TPP Art. 3.1 requires that country-code top-level domain (ccTLD) provide dispute settlement based on principles established in the Uniform Domain-Name Dispute-Resolution Policy. TPP Art. 3.2 requires that there be online public access to a reliable and accurate database of contact information concerning domain-name registrants. These requirements are in KORUS, but do not appear in TRIPS.

As explained in a note provided by cyberlaw expert Wendy Seltzer, these provisions preempt expert policy debates currently under way at the Internet Corporation for Assigned Names and Numbers (ICANN): ${ }^{31}$

As the United States knows, both the UDRP and WHOIS are subjects of active policy debate in ICANN's multi-stakeholder forum. It damages that process to freeze elements of it through trade agreements.

Country Code TLDs (ccTLDs, such as .uk, .br, .pe, .mx) are operated by groups in their countries, some governmental, some not. They are not under contract to ICANN (unlike the generic TLDs), and are free to develop their own policies, to reflect their own national laws and local needs. Extending U.S.-based law to them would deprive us of the experimentation and better speech-protections they can offer. (Domain names matter both for their expressive value as pointers to speech, and for the speech they convey directly.)

The UDRP was one of the earliest-established ICANN policies for gTLDs. More than a decade ago, it was put in place as an arbitration-like procedure for domain/trademark disputes. Since then, several academic studies have cataloged its procedural and

geographical indication of any other Member with respect to goods or services for which the relevant indication is identical with the term customary in common language as the common name for such goods or services in the territory of that Member."

${ }^{30}$ TRIPS Art. 24.6 (defining generic as "the term customary in common language as the common name for such goods or services in the territory of that Member").

${ }^{31}$ Letter from Wendy Seltzer, Fellow, Yale Law School Info. Soc'y Project, to Sean Flynn, Assoc. Dir., Program on Info. Justice \& Intellectual Prop. (Oct. 31, 2011). 
substantive problems, such as forum shopping and unfairness to domain registrants with criticism and parody domains, ${ }^{32}$ and many within ICANN's GNSO have called for the UDRP's review. Some ccTLDs have modified procedures based on the UDRP.

For example, Nominet, the uk registry, has a dispute policy based on the UDRP's framework but with greater free-speech protections, and specific reference to fair use defenses.

WHOIS, the public listing of contact info of domain registrants, is another hotly contested issue here at ICANN. The Article 29 Working Party of European data protection commissioners found likely conflicts with privacy laws, ${ }^{33}$ and these identification databases pose serious problems to speakers and critics in hostile regimes. Iranian activists in the green movement have been questioned in police detention about people identified in domains' WHOIS records. ${ }^{34}$

The proposal is also counter to existing ICAAN Principles for the Delegation and Administration of ccTLDs, which "should recognise that ultimate public policy authority over the relevant ccTLD rests with the relevant government or public authority."35 The WSIS Tunis Agenda for the Information Society - agreed upon by the UN-sponsored World Summit on the Information Society in 2005 - similarly states that "Countries should not be involved in decisions regarding another country's country-code Top-Level Domain (ccTLD). Their legitimate interests, as expressed and defined by each country, in diverse ways, regarding decisions

affecting their ccTLDs, need to be respected, upheld and addressed via a flexible and improved framework and mechanisms." 36

\section{COPYRIGHT AND RELATEd RightS}

\section{A. Art. 4.1- Exclusive Reproduction Rights}

The U.S. proposal includes many dramatic expansions of the international

${ }^{32}$ See Comments of the Noncommercial Users Constituency (NCUC) on the Preliminary GNSO Issue Report on the Current State of the Uniform Dispute Resolution Policy (UDRP), available at http://forum.icann.org/lists/prelim-report-udrp/pdfn9gXwk5UTa.pdf.

${ }^{33}$ See Letter from Peter Schaar, Chairman, Art. 29 Data Protection Working Party, to Vinton G. Cerf, Chairman of Bd. Of Dir., Internet Corporation for Assigned Names and Numbers (ICANN) (June 22, 2006), available at http://www.icann.org/en/correspondence/schaar-to-cerf-22jun06.pdf.

${ }^{34}$ For an older sample of the still-ongoing debate, see Wendy Seltzer, WHOIS redux: Demand privacy in domain name registration, SELTZER.ORG (Oct. 25, 2007), http://wendy.seltzer.org/blog/archives/2007/10/25/whois-redux-demand-privacy-in-domainname-registration.html.

35 Principles for Delegation and Administration of ccTLDs, Presented by Governmental Advisory Committee. 23 February 2000. Available at http://www.icann.org/en/committees/gac/gaccctldprinciples-23feb00.htm

${ }^{36}$ Tunis Agenda for the Information Society, WSIS-05/TUNIS/DOC/6(Rev. 1)-E. 18 November 2005. Available at: http://www.itu.int/wsis/docs2/tunis/off/6rev1.html 
minimum standards on the scope and length of copyright protection, including provisions not reflected in current U.S. law.

TPP Art. 4.1 grants intellectual property rights holders the exclusive right to "prohibit all reproduction ... in any manner or form, permanent or temporary (including temporary storage in electronic form)." Although the language of the U.S. proposed TPP Art. 4.1 was included in KORUS, it is not fully present in U.S. Copyright law. Section $\S 106(1)$ of the Copyright Act does not prohibit reproduction "in any form." It rather prohibits reproduction of the "copyrighted works in copies or phonorecords." ${ }^{37}$ Nor does U.S. law include an extension to "temporary storage in electronic form." U.S. law requires that a copy be "fixed," meaning "sufficiently permanent or stable to permit it to be perceived, reproduced, or otherwise communicated for a period of more than transitory duration." ${ }^{38}$ The DMCA recognizes a safe harbor for "system caching," 39 which is not included in the U.S. TPP proposal.

The distinctions are particularly important for enforcement of copyright on the internet. Lower courts in the U.S. have, for example, held that copyright does not extend to buffer copies on the internet. ${ }^{40}$ Similarly, although not a party to this agreement, the EU Copyright Directive (Directive 2001/29/EC, Article 5) contains an explicit exception for temporary reproductions addressing automated caching. The proposed TPP language could threaten these types of limitations and exceptions in TPP member countries.

It is noteworthy that the TPP language appears to derive from proposals that were rejected in the negotiation of the Basic Proposal for the 1996 WIPO treaties. Language addressing temporary copies was considered in these negotiations but ultimately left out of the treaties. The U.S. proposal seeks to revive debate of these rejected norms in a more limited forum with insufficient transparency.

\section{B. Art. 4.2 - Parallel Importation}

TPP article 4.2 would create a new international legal requirement to provide

${ }^{37}$ See Jodie Griffin, Inconsistencies Between the Trans-Pacific Partnership (TPP) Agreement and US Law, Public Knowledge, www.publicknowledge.org/files/TPP\%20Analysis.pdf

${ }^{38}$ Copyright Act, 17 U.S.C. $§ 101$ (defining that "[c]opies" are material objects, other than phonorecords, in which a work is fixed by any method now known or later developed, and from which the work can be perceived, reproduced, or otherwise communicated, either directly or with the aid of a machine or device. The term "copies" includes the material object, other than a phonorecord, in which the work is first fixed.").

39 Digital Millennium Copyright Act, 17 U.S.C. § 512(b) (1998).

${ }^{40}$ See Cartoon Network LP, LLLP v. CSC Holdings, Inc., 536 F.3d 121 (2d Cir. 2008) (holding that buffer copies are saved for 'more than transitory duration' and are therefore insufficient for a work to be 'fixed'). 
copyright owners an exclusive right to block "parallel trade" of copyrighted works meaning the importation of a copyrighted work from one country where the good is voluntarily placed on the market to another country where the same good at the same price is unavailable. ${ }^{41}$ The language of the U.S. proposed TPP Art. 4.2 is not consistent with current U.S. law, is not required by any multilateral agreement and is not in the best interests of TPP member countries. ${ }^{42}$

The issue of parallel trade arises because rights owners desire the ability to segment markets and determine their own prices and policies for entry into each market. Many countries are disadvantaged by such rights, particularly where they lack a sufficient consumer base to attract market entry at the lowest possible prices. Parallel trade allows distributors to seek supplies of the legitimate copyrighted work in another market where the good is available. If for example, as is often the case, a text book is sold at a higher price in a poor country than in a wealthier one, a supplier in the poor country could purchase the book in the lower priced market and resell it in the domestic market - benefiting both consumers and the local firm.

In recognition of the divergence of legitimate policies between countries, the WTO TRIPS agreement leaves countries free adopt domestic policies on parallel importation through their regimes of exhaustion of intellectual property rights. ${ }^{43}$

The extension of copyrights to parallel trade is unsettled in current U.S. law. The issue was recently litigated in the Supreme Court in Costco v. Omega, but the split decision did not finally resolve whether copyrights prevent parallel importation in the U.S. Regardless, as explained above, many countries in the TPP membership will have different economic interests than the U.S. and may legitimately desire different exhaustion regimes. A recent study in New Zealand for example, described by Alberto Cerda of Knowledge Ecology International, found that its 1998 lifting of bans on parallel importation of copyrighted goods "has not affected the investment in and promotion of New Zealand creative sector, but improved choices and quality of services to retailers and consumers through increased competition, a result similar to Australia." 44

${ }^{41}$ Art. 4.2 ("Each Party shall provide to authors, performers, and producers of phonograms the right to authorize or prohibit the importation into that Party's territory of copies of the work, performance, or phonogram made without authorization, or made outside that Party's territory with the authorization of the author, performer, or producer of the phonogram").

${ }^{42}$ See Alberto Cerda, USTR New Exclusive Right for Copyright Holders: Importation Provision in the Trans Pacific Partnership Agreement (TPPA) (July 5, 2011) http://keionline.org/node/1176

43 TRIPS Art. 6 (providing that "nothing in this Agreement shall be used to address the issue of the exhaustion of intellectual property rights").

${ }^{44}$ Alberto Cerda, USTR New Exclusive Right for Copyright Holders: Importation Provision in the Trans Pacific Partnership Agreement (TPPA) (July 5, 2011) http://keionline.org/node/1176 (citing the 1998 New Zealand Copyright (Removal of Prohibition on Parallel Importing) Amendment Act and the government's 2005 Cabinet Paper on Parallel Importing and the Creative Industries, 


\section{Art. 4.5 - Terms of Copyright Protection}

TPP Art. 4.5 attempts to export the TRIPS-plus and KORUS-plus copyright terms of U.S. law-life of the author plus 70 years, or not less than 95 years from the first publication or 120 years from creation. ${ }^{45}$ Adoption of this provision would double many copyright terms from the TRIPS minimums of publication plus 50 years, or 50 years from creation. ${ }^{46}$

Although the life of the author plus 70 years standard of TPP Art. 4.5 is consistent with U.S. Copyright Act §§ 302(a)-(b), TPP sets the specified terms as the minimum level of protection, whereas U.S. law sets this limit as the ceiling of the term. ${ }^{47}$ TPP Art. 4.5(b) also fails to incorporate the U.S. law presumption that after 95 years from first publication or 120 years after creation, an author's death is presumed, ${ }^{48}$ which can assist some works in entering the public domain.

Length of copyright terms is an area of law where the U.S. model should not be considered an appropriate standard for the rest of the world. The latest terms in the U.S. are the result of the controversial and much criticized "Sonny Bono Copyright Term Extension Act" of 1998, extending the already TRIPS-plus and frequently criticized copyright terms by another 20 years. As a coalition of law professors reported to Congress in opposition to that act at the time, the lengthening of copyright terms "impose severe costs on the American public without providing any public benefit. It would supply a windfall to the heirs and assignees of dead authors (i.e., whose works were first published around 1920) and deprive living authors of the ability to build on the cultural legacy of the past." 49 These views are supported by numerous academic studies finding no public benefit, but great public cost, from extending copyright terms to the current U.S. levels. ${ }^{50}$

http://www.med.govt.nz/templates/MultipageDocumentTOC_5706.aspx).

${ }^{45} 17$ U.S.C. $\S 302$ (2002) (specifying the duration of copyright for works created on or after 1/1/78).

${ }^{46}$ TRIPS Art. 12. The proposal is also in excess of KORUS Art. 18.4.4, providing for terms to be not less than 70 years from the end of the calendar year of the first authorized publication.

${ }^{47}$ See Jodie Griffin, Inconsistencies Between the Trans-Pacific Partnership (TPP) Agreement and US Law, Public Knowledge, www.publicknowledge.org/files/TPP\%20Analysis.pdf

4817 U.S.C. § 302(e) ("After a period of 95 years from the year of first publication of a work, or a period of 120 years from the year of its creation, whichever expires first, any person who obtains from the Copyright Office a certified report that the records ... disclose nothing to indicate that the author of the work is living, or died less than 70 years before, is entitled to the benefit of a presumption that the author has been dead for at least 70 years.").

${ }^{49}$ Statement of Copyright and Intellectual Property Law Professors on the Public Harm from Copyright Extension, http://homepages.law.asu.edu/ dkarjala/opposingcopyrightextension/commentary/opedltr.html

50 See, e.g., DOUglas GOMERY, RESEARCh RePORT: THE ECONOMICS OF TERM EXTENSION FOR MOTION 


\section{Art. 4.7(b)}

TPP Art. 4.7 would require that parties provide any person "acquiring or holding any economic right in a work" by virtue of a contract, "be able to exercise that right in that person's own name and enjoy fully the benefits derived from that right." As Jodie Griffin of Public Knowledge notes, this provision is likely consistent with U.S. law but "could be construed to grant authorship to employers or contractors without meeting the requirements [of] the work made for hire definition in $\S 101$ " of the U.S. Copyright Act, and could also conflict with termination rights in $§ 203$.

\section{E. Arts. 4.9(a), 16.3 - Technological Protection Measures}

TPP Art. 4.9 proposes new anti-circumvention standards that go beyond the high and controversial standards included in the Anti-Counterfeiting Trade Agreement (ACTA, Art. 27.6(a)(i)), and KORUS (Art. 18.4.7(a)(i)), and are not fully consistent with current U.S. law.

Policies governing the creation or use of circumvention technology must be carefully crafted to avoid dampening technological innovation and freedom of speech. There are many lawful and appropriate uses of technologies that permit copying of digitally locked material. Documentary filmmakers, for example, may use such devices to lawfully quote other films in their new works. And it is lawful under U.S. law to "jailbreak" a locked phone to run software not authorized by the hardware seller.

The ACTA and KORUS anti-circumvention standards are very strong and controversial forms of these norms. The TPP proposal is more extreme, eliminating from these standards the requirement that any punished use of circumvention equipment occur "knowingly or having reasonable grounds to know" that the action is illegal.51 The TPP standard would thus appear to allow the punishment of circumvention of technical protection measures regardless of any intent to infringe copyright. The TPP also removes the proviso in ACTA that the minimum standards

PiCTURES; Marci A. Hamilton, Copyright Duration and the Dark Heart of Copyright, 14, Cardozo Arts \& Entertainment Law Journal 655 (1996); Dennis S. Karjala, The Term of Copyright, in Growing PAINS: AdAPting COPYRight FOR LiBrariEs, EdUCATION, AND SOCIETy (LAURA N. GASAWAY ED., PUBLISHED By FRED B. Rothman \& Co. 1997); Cecil C. Kuhne III, The Steadily Shrinking Public Domain: Inefficiencies of Existing Copyright Law in the Modern Technology Age, 50 Loy. L. Rev. 549-563 (2004); Edward Rappaport, Copyright Term Extension: Estimating the Economic Values, Congressional Research Service, Library of Congress, May 11, 1998; J.H.Reichman, The Duration of Copyright and the Limits of Cultural Policy, 14 Cardozo Arts \& Entertainment L.J. 625 (1996). See also Stephen Breyer, The Uneasy Case for Copyright: A Study of Copyright in Books, Photocopies, and Computer Programs, 84 Harv. L. Rev. 281, 324 (1970) (opposing what became the 1976 extensions).

${ }^{51}$ ACTA Art. 27.6(a)(i) (prohibiting "the unauthorized circumvention of an effective technological measure carried out knowingly or with reasonable grounds to know."). 
only apply to anti-circumvention measures "to the extent provided by its law," which is a potentially broad exception allowing countries without such protection in their current law to continue not providing such protections.

The TPP proposal is not entirely consistent with U.S. law.

- Whereas DMCA $\S 1201(\mathrm{a})(2)(C)$ prohibits products "marketed" for use in circumventing a technological protection measure, 52 TPP Art. 4.9(a)(ii)(A) extends to products that are "promoted, advertised" for this purpose.

- DMCA § 1201(a)(2)(A) extends only to products designed "for the purpose of circumventing," while the TPP 4.9(a)(ii)(C) extends to any product "for the purpose of enabling or facilitating the circumvention," a potentially broader standard.53 This also goes beyond ACTA Art. 27.6(a)(ii). 54

- Art. 4.9(a), by virtue of the requirement to include "the remedies and authorities listed in subparagraphs (a), (b), and (f) of Article [15.5] as applicable to infringements," requires "the imposition of actual terms of imprisonment when criminal infringement is undertaken for commercial advantage or private financial gain." This is inconsistent with 17 U.S.C. $\S$ 1204, which permits fines or imprisonment for violations of anticircumvention standards. ${ }^{55}$

\section{F. Art. 4.9(d) - Exceptions and Limitations}

TPP Art. 4.9 proposes confining limitations and exceptions to circumvention liability to a set of provisions that are similar to, but not identical to, the various exceptions and limitations in DMCA $\S 1201.56$ Adopting this standard would restrict countries from developing their own exceptions to liability not based on present U.S.

${ }^{52} 17$ U.S.C. § 1201(a)(2)(C) (prohibiting product, service, device, component, or part thereof that "is marketed by that person or another acting in concert with that person with that person's knowledge for use in circumventing a technological measure that effectively controls access to a work protected under this title.").

${ }^{53}$ Jodie Griffin, Inconsistencies Between the Trans-Pacific Partnership (TPP) Agreement and US Law, Public Knowledge, www.publicknowledge.org/files/TPP\%20Analysis.pdf

${ }^{54}$ ACTA Art. 27.6(a)(ii) (prohibiting "the offering to the public by marketing of a device or product, including computer programs, or a service, as a means of circumventing an effective technological measure.").

${ }_{55}$ Jodie Griffin, Inconsistencies Between the Trans-Pacific Partnership (TPP) Agreement and US Law, Public Knowledge, www.publicknowledge.org/files/TPP\%20Analysis.pdf

${ }^{56}$ See TPP Art. 4.9(d) (providing that parties "shall confine exceptions and limitations to measures implementing subparagraph (a) to the following activities"). 
law. ACTA more broadly permits parties to "adopt or maintain appropriate limitations or exceptions" to anti-circumvention liability and clarifies that circumvention liability obligations are "without prejudice to the rights, limitations, exceptions, or defences to copyright or related rights infringement under a Party's law." 57

The TPP proposal does not track the DMCA limitations in every detail. Importantly, Art. 4.9(d)(viii) raises the evidentiary standard currently applied in U.S. law to develop anti-circumvention exceptions. As explained by Jodie Griffen of Public Knowledge, the U.S. Library of Congress currently grants exemptions to U.S. anti-circumvention restrictions where there is "sufficient evidence" of a substantial adverse effect on non-infringing uses, and has noted that "how much evidence is sufficient will vary," and "is never the only consideration in the rulemaking process." 58 TPP Art. 4.6(viii) raises the standard from "sufficient evidence" to "substantial evidence" and implies that this evidence would be the only factor in the determination. 59

\section{G. Art. 4.10 - Rights Management Information}

TPP Art. 4.10 proposes a new regime of protection of rights management information that lowers the threshold for violation and expands the scope of prohibited activities. The standard proposed goes beyond similar TRIPS-plus provisions in KORUS, ACTA, and DMCA. ${ }^{60}$

Current U.S. law only prohibits the distribution, importation or public performance of works knowing that rights management information has been removed or altered. ${ }^{61}$ The TPP proposal also prohibits a person from broadcasting, communicating, or making available the work to the public. ${ }^{62}$ It is noteworthy that

${ }^{57}$ ACTA § 5, Art. 27.8.

${ }^{58}$ Jodie Griffin, Inconsistencies Between the Trans-Pacific Partnership (TPP) Agreement and US Law, Public Knowledge, www.publicknowledge.org/files/TPP\%20Analysis.pdf (quoting 73 Fed. Reg. 58075).

${ }^{59}$ TPP Art. 4.9(d)(viii) (permitting exceptions for "noninfringing uses of a work, performance, or phonogram in a particular class of works, performances, or phonograms when an actual or likely adverse impact on those noninfringing uses is demonstrated in a legislative or administrative proceeding by substantial evidence; provided that any limitation or exception adopted in reliance upon this clause shall have effect for a renewable period of not more than three years from the date of conclusion of such proceeding.").

${ }^{60}$ See 17 U.S.C. § 1202; ACTA Art. 27.7; KORUS Art. 18.4.8(a).

${ }^{61} 17$ U.S.C. $§ 1202$ (b)(3) ("distribute, import for distribution, or publicly perform works, copies of works, or phonorecords, knowing that copyright management information has been removed or altered without authority of the copyright owner or the law.").

${ }^{62}$ See Jodie Griffin, Inconsistencies Between the Trans-Pacific Partnership (TPP) Agreement and US Law, Public Knowledge, www.publicknowledge.org/files/TPP\%20Analysis.pdf 
the "making available" standard is in other U.S. free trade agreements and in the WIPO copyright treaties, but is not reflected in U.S. law.

The definition of "rights management information" in TPP Art. 4.10(c) is similar to that in the DMCA, except it specifically omits the exception for "public performances of works by radio and television broadcast stations" in DMCA $\S \S$ 1202(c)(4),(5). ${ }^{63}$

\section{H. Art. 5 - "Making available"}

TPP Art. 5 would require each party to provide the exclusive right to prohibit the "making available to the public of their works in such a way that members of the public may access these works from a place and at a time individually chose by them." There is a circuit split on the issue of whether §106(3) of the U.S. Copyright Act includes a "making available" right absent actual transfer. ${ }^{64}$

\section{Art. 6: Related Rights}

TPP Art. 6 incorporates various provisions from the WIPO Performances and Phonograms Treaty (WPPT) ${ }^{65}$ and KORUS. There are some provisions that exceed even these agreements.

- TPP Art. 6.1 closely resembles KORUS Art. 18.6.1 but adds the last sentence, "[a] performance or phonogram shall be considered first published in the territory of a Party in which it is published within 30 days of its original publication."

- TPP Art. 6.3 adds to KORUS Art. 18.6.3 and WPPT Art. 10 "producers of phonograms" in addition to performers.

- TPP Art. 6.5 alters the KORUS definition of "broadcasting" by adding that it does not include transmissions over computer networks or any transmission where the time and place of reception may be individually chosen by members of the public (e.g. Netflix, Hulu). The U.S. Copyright

${ }^{63} 17$ U.S.C. §§ 1202(c)(4), (5) (“(4) With the exception of public performances of works by radio and television broadcast stations, the name of, and other identifying information about, a performer whose performance is fixed in a work other than an audiovisual work. (5) With the exception of public performances of works by radio and television broadcast stations, in the case of an audiovisual work, the name of, and other identifying information about, a writer, performer, or director who is credited in the audiovisual work."). See Jodie Griffin, Inconsistencies Between the Trans-Pacific Partnership (TPP) Agreement and US Law, Public Knowledge,

www.publicknowledge.org/files/TPP\%20Analysis.pdf

${ }^{64}$ Jodie Griffin, Inconsistencies Between the Trans-Pacific Partnership (TPP) Agreement and US Law, Public Knowledge, www.publicknowledge.org/files/TPP\%20Analysis.pdf

${ }^{65}$ World Intellectual Property Organization Performances and Phonograms Treaty, adopted by Diplomatic Conference at Geneva, Dec. 20, 1996, 36 I.L.M. 76 [WPPT]. 
Act does not include this definition. 66

\section{PATENTS}

\section{A. Arts. 8.1, 8.12 FN 15 - Easing and Expanding Standards of Patentability}

TPP Art. 8.1 contains a controversial TRIPS-plus provision, most relevant to pharmaceutical patents, that the scope of patentability include "any new forms, uses, or methods of using a known product; and a new form, use, or method of using a known product.... even if such invention does not result in the enhancement of the known efficacy of that product". This language goes far beyond definition of patentability contained in TRIPS Art. 27.1, which merely states that "patents shall be available for any inventions, whether products or processes, in all fields of technology provided that they are new, involve an inventive step and are capable of industrial applicability."67

Art. 8.1 could require countries to open flood gates to patent applications on minor modifications or variations of existing chemical entities; on new uses or methods of using existing medicines, ${ }^{68}$ or on new formulations, dosages, and combinations. ${ }^{69}$ Countries would be required to do so even if there is no enhancement of therapeutic efficacy - indeed there could be a decrease in therapeutic effect. Each new patent on new forms, uses, or formulation of an existing medical product will result in a new 20-year patent running from the date of patent application, thereby "evergreening" monopoly rights on the underlying medical product.70

TPP Art. 8.1 is inconsistent with the laws of other TPP negotiating countries, including Australia, Malaysia, and Vietnam. ${ }^{71}$ But the most direct target of the

\footnotetext{
${ }^{66}$ See Jodie Griffin, Inconsistencies Between the Trans-Pacific Partnership (TPP) Agreement and US Law, Public Knowledge, www.publicknowledge.org/files/TPP\%20Analysis.pdf

${ }^{67}$ TPP Art. 8.1 also goes beyond KORUS Art. 18.8.1, which altered that TRIPS standard by adding "each Party confirms that patents shall be available for any uses or methods of using a known

68 See Graciela Andrei et al, Topical Tenofovir, a Microbicide Effective against HIV, Inhibits Herpes Simplex Virus-2 Replication, 10 Cell Host \& MicroBe, 379-89 (2011) ( describing use of tenofovir, and AIDS drug, to treat hepatitis for herpes simplex virus-2 prophylaxis).

${ }^{69}$ e.g. heat-stable ritonavir/lopinavir or extended release formulations.

${ }^{70}$ For example, since the filing of the original patent application on ritonavir in 1980 there have been over 800 families of ever-greening patent applications, most first filed in the U.S. Those patent applications filed in 2009 will extend exclusivity period from the original 2000 date to 2029 twenty-nine extra years and counting. See World Intellectual Property Organization, PATENT LANDSCAPE REPORT ON RITONAVIR (2011), available at http://www.wipo.int/export/sites/www/patentscope/en/programs/patent_landscapes/reports/do cuments/ritonavir_plr_08112011_with_old_cover.pdf. Note, some of the ritonavir patents filed are process rather than product patents.

${ }^{71}$ See Dangers for Access to Medicines in the Trans-Pacific Partnership Agreement: Comparative Analysis of the U.S. Intellectual Property Proposal and Australian Law, PuBlic Citizen, [hereinafter
} product." 
section is probably India, although India is not a TPP party. ${ }^{72}$ The TPP proposal is clearly drafted to counter the policy embodied in the 2005 Amended India Patents Act section $3(d)^{73}$, which prohibits the granting of patents for "the mere discovery of a new form of a known substance which does not result in the enhancement of the known efficacy of that substance or the mere discovery of any new property or new use for a known substance or of the mere use of a known process, machine or apparatus unless such process results in a new product or employs at least one new reactant." India's section 3(d) was enacted to reduce ever-greening of pharmaceutical patents, and is widely recognized as a pro-public health and TRIPScompliant exception to patentability. ${ }^{74}$ It has been offered as a model for other developing countries to follow. ${ }^{75}$

\section{B. Art. 8.2 - Eliminating Exclusions from Scope of Patentable Subject Matter}

In direct contradiction to TRIPS Art. 27.3, TPP Art. 8.2 would require that "each party shall make patents available for ... (a) plants and animals, and; (b) diagnostic, therapeutic, and surgical methods for the treatment of humans or animals." The application of patents to these areas, mirrored in KORUS Art. 18.8.2,76 is expressly

Public Citizen TPP-Australian Law Comparison], available at http://www.citizen.org/Page.aspx?pid=5025\&frcrld=1; Dangers for Access to Medicines in the TransPacific Partnership Agreement: Comparative Analysis of the U.S. Intellectual Property Proposal and Malaysian Law, PUBLIC CiTIzEN, [hereinafter Public Citizen TPP-Malaysian Law Comparison], available at http://www.citizen.org/documents/Malaysia-chart.pdf; Vietnam and the Trans-Pacific Partnership Agreement: Access to Medicines Risk for a PEPFAR Partner, PubliC Citizen \& HEALTH GAP, available at http://www.citizen.org/documents/Vietnam-and-the-Trans-Pacific-Partnership-Agreement.pdf.

${ }^{72}$ Public Citizen, Health GAP, I-MAK \& Third World Network, Briefing Memo: Analysis of the Leaked U.S. Paper on Eliminating Patent Pre-Grant Opposition, PuBlic Citizen (July 7, 2011), available at http://www.citizen.org/documents/analysis-of-leaked-US-paper-on-eliminating-pregrantopposition.pdf

73 The Patents (Amendment) Act, 2005, No. 15, Acts of Parliament, 2005, § 3, India Code (2005).

${ }^{74}$ MSF Campaign for Access to Essential Medicines, TPP Issue Brief - September 2011, [hereinafter MSF TPP Issue Brief] available at http://www.doctorswithoutborders.org/press/2011/MSF-TPP-Issue-Brief.pdf; see Janice M. Mueller, The Tiger Awakens: The Tumultuous Transformation of India's Patent System and the Rise of Indian Pharmaceutical Innovation, 68 U. PITT. L. Rev. 491 (2007); Amy Kapczynski, Harmonization and its Discontent: A Case Study of TRIPS Implementation in India's Pharmaceutical Sector, 97 CAL. L. REV. 1571-1650 (2009); Sudip Chaudhuri, Chan Park \& K. M. Gopakumar, Five YEARS InTO THE ProduCT PATENT REGiME: INDIA'S RESPONSE (2010), available at apps.who.int/medicinedocs/documents/s17761en/s17761en.pdf..

${ }^{75}$ Carlos Correa, Guidelines for the Examination of Pharmaceutical Patents: Developing a Public Health Perspective 6-25 (Jan. 2007), available at http://www.iprsonline.org/resources/ docs/Correa_Patentability\%20Guidelines.pdf (drawing on sec. 3(d), and recommending that developing countries adopt comparable strict patentability standards, e.g., that they treat new formulations, compositions, salt patents, and enantiomers as obvious and/or as exceptions to patentability).

${ }^{76}$ KORUS Art. 18.8.2 (preventing the exclusion of "diagnostic, therapeutic, and surgical procedures for the treatment of humans or animals."). 
contrary to the right to exclude patents on such subject matter found in TRIPS Art. 27.3.77 TPP art. 8.2 is also contrary to the actual practice of U.S. law which allows patents on medical procedures but precludes use of such patents to seek remedies against medical practitioners. ${ }^{78}$ The provision runs counter to the current law in several TPP member countries. ${ }^{79}$

\section{Art. 8.7 - Limiting Revocation and Eliminating Pre-Grant Opposition}

TPP art. 8.7 contains TRIPS-plus restrictions on the grounds for patent revocation and on processes for permitting pre-grant opposition of patent applications.

TRIPS Art. 32 requires "[a]n opportunity for judicial review of any decision to revoke or forfeit a patent." The TPP proposal, modeled on KORUS Art. 18.8.4, restricts the grounds upon which a patent may be revoked to "grounds that would have justified a refusal to grant the patent," and specifies that such grounds to include fraud, misrepresentation or inequitable conduct. Under TRIPS art. 32 there are no limitations on grounds for revocation, only a requirement of judicial review; likewise under the earlier Paris Convention, countries have the right to revoke a patent, including specifically for any abuse of the patent that cannot be remedied through a compulsory license..$^{80}$

TPP Art. 8.7 additionally restricts the use of pre-grant oppositions. It provides that if proceedings permit a third party to oppose the grant of a patent, the "Party shall not make such proceedings available before the grant of the patent." Pre-grant oppositions allow opportunities to contest a patent as it is filed, providing a potentially important source of information to patent examiners and generally improving patent quality. ${ }^{81}$ The U.S. has justified this restriction (in a leaked

\footnotetext{
${ }^{77}$ TRIPS Art. 27.3 (emphasis added) (which provides that "[m]embers may also exclude from patentability: (a) diagnostic, therapeutic and surgical methods for the treatment of humans or animals; (b) plants and animals other than micro-organisms, and essentially biological processes for the production of plants or animals other than non-biological and microbiological processes.

${ }^{78}$ See 35 U.S.C. $§ 287$ (c).

${ }^{79}$ See Public Citizen \& Health GAP (noting that the laws in "Vietnam and many other countries exclude diagnostic, therapeutic and surgical methods from patentability."); Public Citizen TPPAustralian Law Comparison (noting that the proposed language would eliminate a flexibility recognized by Art. 17.9.2 of AUSFTA); Public Citizen TPP-Malaysian Law Comparison (explaining that Section 13(1) of Malaysia's Patents Act of 291 of 1983 "expressly excludes treatment by surgery or therapy and diagnostic methods on the living human or animal body from patent protection.").

${ }^{80}$ Paris Convention for the Protection of Industrial Property, Art. 5(A)(3).

${ }^{81}$ See Dietmar Harhoff, Frederic M Scherer, Katrin Vopel, Erratum to "Citations, family size, opposition and the value of patent rights" Research Policy, Volume 33, Issue 2, March 2004, Pages 363-364 (noting that patents tested by opposition systems have greater value); Tahir Amin et al., Expert Review of Drug Patent Applications: Improving Health in the Developing World, 28:5 Health
} 
Memorandum) as in the interest of patent offices. ${ }^{82}$ The U.S. position and its reasoning was promptly criticized by public health advocates as removing an important tool for "preventing patent applicants from gaining patent monopolies based on weak for erroneous information, for improving the quality and efficiency of patent office examinations, and for safeguarding access to medicines." 83

The U.S. TPP proposal would require change in Australia's law, which already includes a pre-grant opposition system. ${ }^{84}$ As in other areas of the TPP, the clearest target of the proposal may be India. Adopting this proposal would prevent the countries of the TPP from adopting the kind of pre-grant opposition processes that India has found useful. ${ }^{85}$

\section{Art. 8.9- Unlimited Amendments to Patent Applications}

Whereas Art. 8.7 makes it harder to challenge and revoke patent rights, art. 8.9 makes it much easier to successfully apply for them. Art. 8.9 forces countries to allow patent applicants to make multiple amendments to their patent claims prior to approval on the merits. TRIPS does not require Members to allow amendment of patent applications. KORUS Art. 18.8.8 includes a TRIPS-plus requirement to allow applicants at least one opportunity to make amendments, corrections, and observations in connection with their applications. The US TPP proposal would

Affairs, 948, 951-52 (Aug. 25, 2009), available at

http://content.healthaffairs.org/content/28/5/w948.full.pdf+html (arguing that pre=grant

opposition systems lead to efficiency gains without causing problems of abuse of the system or rising costs of delay).

${ }^{82}$ See Pre-Grant Opposition, PubliC Citizen, available at http://www.citizen.org/documents/Leaked-US-TPPA-paper-on-eliminating-pre-grantopposition.pdf. ("A lengthy or onerous pre-grant patent opposition system place undue burdens on patent applicants and create additional costs to patent offices, thereby causing uncertainty and deterring innovators and enterprises that would otherwise bring innovative products and services to TPP partners.").

${ }^{83}$ Public Citizen, Health GAP, I-MAK \& Third World Network, Briefing Memo: Analysis of the Leaked U.S. Paper on Eliminating Patent Pre-Grant Opposition, Public Citizen (July 7, 2011), available at http://www.citizen.org/documents/analysis-of-leaked-US-paper-on-eliminating-pregrantopposition.pdf.; K.M. Gopakumar \& Sanya R. Smith, IPR Provisions in FTAs: Implications for Access to Medicines, in Intellectual Prop. \& Access to Med: Papers \& Perspectives, World Health Org. 141, 144 (2010) (criticizing the elimination of pre-grant opposition in U.S. FTAs).

${ }^{84}$ Public Citizen TPP-Australian Law Comparison (commenting that the TPP proposal would proscribe the "pre-grant opposition [process] in Australia [which] improves patent quality with minimal interference to well-drafted patent applications.").

${ }^{85}$ See Shamnad Basheer, India's Tryst With TRIPS: The Patents (Amendment) Act, 2005, 1 Indian J.L. \& TeCH. 15, 26; Peter Drahos, The Jewel in the Crown: India's Patent Office and Patent-Based Innovation, in INTELLECTUAL PROPERTY POLICY REFORM 80, 95 (noting 150 pre-grant oppositions filed by Indian generic industry since 2005). 
make the number of amendments unlimited.

The interests of many patent offices will be best served by maximizing pre-grant oppositions and minimizing opportunities to amend patent claims after they are filed. In such a system, companies have incentives to only file their strongest claims, leading to a lower volume of weak applications and stronger overall patent value. ${ }^{86}$ Under the U.S. TPP proposal, applicants have more opportunities to game the system in their favor and can demand the elongation of processes. They can, for example, respond to a challenge or weakness in their application by adding entirely new claims. They will lack an incentive to make all possible claims in an initial completed application. ${ }^{87}$ Patent applicants will be rushed to file incomplete applications to gain priority dates over other potential inventors, and will not be penalized for filing incomplete or imperfect claims only to correct them after.

\section{E. Art. 8.10 and Art. 8.11- Minimize Required Disclosure}

TPP Arts. 8.10 and 8.11 reduce flexibility that countries have under TRIPS to design domestic patent disclosure standards. TPP Art. 8.10 and 8.11 require that a disclosure be considered sufficient if it "allows the invention to be made and used by a person skilled in the art, without undue experimentation." ${ }^{8}$ This provision may impede flexibility in implementing TRIPS Art. 29.1's permission for a disclosure standard requiring disclosure of the best mode for carrying out the invention. In addition, there could be other disclosure requirements of interest to TPP members, including "information concerning the applicant's foreign applications and grants." 89 A country might also require, for example, that the description be sufficient to allow a person skilled in the art to be able to apply the technology in the country of the application. Or a country might want to condition approval of the application on disclosure of use of any traditional knowledge or genetic resources in order to

${ }^{86} \mathrm{Cf}$. Dietmar Harhoff, Frederic M Scherer, Katrin Vopel Erratum to "Citations, family size, opposition and the value of patent rights" Research Policy, Volume 33, Issue 2, March 2004, Pages 363-364 (finding that patents which are upheld in opposition procedures are particularly valuable).

${ }^{87} \mathrm{~A}$ similar problem occurs as a result of TPP-2 Art. 9(8)(a), which makes the access window toll upon "commencement," rather than completion, of the marketing approval process.

88 TPP Art. 8.10. Without any TRIPS counterpart, TPP Art. 8.11 specifies that "Each Party shall provide that a claimed invention is sufficiently supported by its disclosure if the disclosure reasonably conveys to a person skilled in the art that the applicant was in possession of the claimed invention as of the filing date." Cf. KORUS Art. 18.8.10(a) (going further than TPP by requiring that a claim invention is sufficiently supported by its disclosure "if the disclosure allows a person skilled in the art to extend the teaching therein to the entire scope of the claim, thereby showing that the applicant does not claim subject matter which the applicant had not recognized and described or possessed on the filling date.").

${ }^{89}$ TRIPS, art. 29.2 
facilitate access and benefit sharing. ${ }^{90}$ Finally, a country might require disclosure of the generic name of a pharmaceutical product that incorporates the subject matter of the patent application to ease patent searches on medicines.

\section{F. Art. 8.12 - Industrial Applicability/Utility}

TPP Art. 8.12 imposes a weak, U.S.-centric definition of "industrial applicability" on TPP members. TRIPS Art. 27.1 fn. 5 permits Members to define "industrial application" to be synonymous with the term "useful," and does not impose any other definition on the term. This was included to permit the U.S. to continue to implement its own standard of a very lax standard. ${ }^{91}$ TPP Art. 8.12 goes further, however, in exporting the lax U.S. standard, requiring that a claimed invention be considered industrially applicable "if it has a specific, substantial, and credible utility." 92 This weaker standard, based on U.S. law, could be used by firms to press for the patenting of "useful" ideas such as diagnostic, surgical, and therapeutic methods, new uses of known medicines, business methods, and research tools - the extension of patents to which in the U.S. is the subject of frequent academic critique. This provision appears to be designed to foreclose stricter "industrial applicability" standards that in some jurisdictions require a showing that the invention will result in an actual industrial product. ${ }^{93}$

\section{Patent and Data-Related Rights}

\section{A. TPP-2 Art. 8.6 - Lengthening Patent Term to Compensate for Delays}

TPP-2 Art. 8.6 would require TPP members to grant extensions of patent terms beyond the TRIPS 20-year minimum patent term to compensate both for delays in patenting and in granting marketing approval. Patent term extensions delay the introduction of generic products into a market, maintaining monopoly protections and higher prices during the extension.

TRIPS Art. 33 requires a patent term of twenty years. TRIPS does not require extensions beyond the 20-year life of a patent for delays in granting a patent or

90 See Disclosure Requirements: Ensuring mutual supportiveness between the WTO TRIPS Agreement and the CBD. http://www.iprsonline.org/resources/docs/Disclosure req_book.pdf; http://www.iprcommission.org/papers/pdfs/final report/Ch4final.pdf.

${ }^{91}$ See Public Citizen \& HEAlth GAP (commenting that the "U.S. patentability standard of specific, substantial and credible utility is more lenient than the industrial applicability standard used by Vietnam and many other countries."); Public Citizen TPP-Malaysian Law Comparison (pointing out that TPP Art. 8.12 seeks to "impose the U.S. patentability test ... [which is] broad enough to cover inventions without true industrial application.").

92 The language is similar to KORUS Art. 18.8.10(b).

93 See UNCTAD-ICTSD, Resource Book on TRIPS and Development: An Authoritative AND PRACTiCe GUIDE TO THE TRIPS AGREEMENT, 361 (2005). 
marketing approval. The 20-year standard was developed in recognition of the known delays encountered through the examination process.

Mandatory patent term extensions have been a highly controversial aspect of the U.S. post-TRIPS trade agenda on pharmaceutical policy. ${ }^{94}$ As part of the May $10^{\text {th }}$ 2007 New Trade Deal, implemented in the Peru FTA, patent term extensions for any reason were made optional rather than mandatory. The Peru FTA allowed both countries to exempt pharmaceutical products from patent extension requirements. The U.S. TPP-2 proposal would require patent extensions for unreasonable delays in product registration or issuance of a patent without the May $10^{\text {th }}$ exemption, thereby punishing patients for bureaucratic delays.

The TPP proposal is KORUS-plus. TPP-2 Art. 8.6 requires an increase in patent terms beyond 20 years to compensate for "unreasonable" delay in the granting of a patent, defined as a delay of more than four years from the date of filing of the application - the same as KORUS - or two years after a request for examination one year shorter than KORUS. ${ }^{95}$ This requirement is broadly consistent with U.S. law, which has a three-year window. ${ }^{96}$ In addition, TPP-2 Art. 8.6 requires additional term extensions for regulatory delays in approving marketing of pharmaceutical products, including for patents that merely cover a new method of making or using a pharmaceutical product. As in other areas of TPP, although patent term extensions are mandatory, the limitation of patent term extensions, e.g. to a maximum of no more than 5 years and no more than one extension (both attributes of current U.S. law ${ }^{97}$ ) are permissive. ${ }^{98}$

The so-called Access Window features of TPP-2 Art. 8.6(e) is subject to Art. 9.2(b) or (d), which will be discussed further below.

The predictable impact of patent term extensions is to lengthen monopolies and thereby raise the medicines bill for member countries. Moreover, the time pressure of early patent examination and early marketing approval might result in overextended patent offices granting invalid patents and in harried, drug regulatory registering unsafe or inefficacious medicines. This is especially a problem as the

${ }^{94}$ See United States House Of Representatives Committee On Government Reform - Minority Staff Special Investigations Division, Trade Agreements And Access To Medications Under The Bush ADMINISTRATION (June 2005).

95 KORUS Art. 18.8.6.

${ }^{96}$ If the USPTO fails to issue a patent within three years from the actual U.S. filing date, it must extend the patent term one day for each day beyond the three-year period. 35 U.S.C. $\$ 154(b)(1)(B)$.

${ }^{97}$ See 35 U.S.C. \$156. The period of restoration extends from the original expiration date of the patent; however, the total patent term, with restoration, following FDA market approval may not exceed fourteen years. $\$ 156(\mathrm{c})(3)$.

98 TPP-2 Art. 8.6(d) (permitting regulatory-delay patent term extensions to be limited to a single adjustment for each new pharmaceutical product and for the basis of the adjustment to be the first marketing approval granted to a new pharmaceutical product). 
international volume of pharmaceutical patent applications and marketing approval applications grows overwhelming countries, especially developing countries, with weak regulatory capacity.

\section{B. TPP-2 Art. 9.2 - Expanded Data Exclusivity}

TPP-2 Art. 9.2 requires data exclusivity, a very strict form of data protection that is in excess of TRIPS requirements and negates the pro-development flexibilities of the 2007 New Trade Deal. ${ }^{99}$ The U.S. proposal on data exclusivity is a "TRIPS-plus provision that restricts access to essential clinical trial data . . . [and] prevent[s] generic manufacturers from using existing clinical research to gain regulatory approval of their medicines, forcing them to perform duplicate clinical trials or wait for the 'data monopoly' period to end."100 In essence, data exclusivity prevents a drug regulatory agency from referencing regulatory data submitted by a prior registrant and from relying on the fact of prior registration anywhere else. Introducing data exclusivity threatens the registration of generic versions of medicines and creates a system conducive to creating monopolies.

Data exclusivity is not required by TRIPS. In fact, during the negotiation of TRIPS Art. 39.3, the U.S. proposal that TRIPS incorporate a data exclusivity standard was flatly rejected by the negotiating parties.101 TRIPS Art. 39.3 merely requires protection only against the "unfair commercial use" of "undisclosed" data required to be submitted for marketing approval of a "new chemical entity."102 TPP-2 Art. 9.2(a) and (b), patterned on KORUS Art. 18.9.1, abandons the inherent flexibilities in TRIPS Art. 39.3 and imposes U.S.-style data monopolies.

- Rather than banning only the unfair commercial use of information, which could allow for registration authorities to use registration-related

${ }^{99}$ MSF TPP Issue Brief at 5 (explaining that data protection or data exclusivity is a "TRIPS-plus provision that restricts access to essential clinical trial data ... [and] prevent [s] generic manufacturers from using existing clinical research to gain regulatory approval of their medicines, forcing them to perform duplicate clinical trials or wait for the 'data monopoly' period to end." Introducing provisions for data protection in conjunction with a provision for patent term extension greatly threaten the registration of generic versions of medicines and creates a system conducive to creating monopolies).

100 MSF Campaign for Access to Essential Medicines, TPP ISSUE BRIEF (September 2011), available at http://www.doctorswithoutborders.org/press/2011/MSF-TPP-Issue-Brief.pdf.

${ }^{101}$ Carlos Correa and Abdulqawi Yusuf, Intellectual Property and International Trade, The TRIPs Agreement, Kluwer Law International, (London-Cambridge 1998); Daniel Gervais, TRIPS Agreement Drafting History and Analysis, (Sweet \& Maxwell. 1998) pp. 182-183.

102 See Carlos Correa, Protecting Test Data for Pharmaceutical and Agrochemical Products under Free Trade Agreements, in Negotiating Health: Intellectual property and AcCess to Medicines (2006) (explaining that, under TRIPS, the reliance on prior reviewed data by a regulation authority to approve a generic version of the same drug need not be considered a "commercial use" of the data); Brook K. Baker, Ending Drug Registration Apartheid: Taming Data Exclusivity And Patent/Registration Linkage, 34 AM. J. LAW \& MEDICINE 303-44(2008). 
information to grant marketing approval of generic drugs, ${ }^{103}$ the TPP-2 data exclusivity proposal bans reference and reliance registration of any new product "based on" safety and efficacy information submitted to it or to another country for an originator product. ${ }^{104}$

- The TPP-2 data exclusivity provision abandons the TRIPS provision that protection only be required for "undisclosed" information and now requires protection for all data whether previously disclosed or not. Often clinical trial data is made public in various ways, including by funders, registration authorities, and academic publication. Thus, TPP-2 would require granting of exclusive rights for information that is already in the public domain and is in no sense a trade secret.

- The TPP-2 data exclusivity proposal also abandons the TRIPS rule that requires protection only for "new chemical entities" and instead requires protection of new pharmaceutical product that might incorporate existing chemical entities.

- In addition, TPP-2 Art. 9.2(c) and (d) both require an additional threeyear term of exclusivity for data submitted for approval of a new use or form of an approved chemical entity. ${ }^{105}$ Moreover, as in U.S. law, there can be successive three-year data exclusivity extensions, meaning that data exclusivity, like patents, can be ever-greened.

The U.S. TPP-2 proposal abandons data-exclusivity flexibilities adopted in the 2007 New Trade Policy and thereafter granted Peru and Colombia in their FTAs with the U.S. Like TRIPS Art. 39.3, the Peru and Colombia FTAs' data exclusivity provision is limited to new chemical entities. Contrary to U.S. law imposing strict exclusivity periods and the TPP-2 draft which requires "at least" five years of exclusivity, the Peru and Columbia FTAs required data exclusivity for an undefined "reasonable period." The Peru and Colombia FTAs also included a use-or-lose it restriction on data exclusivity whereby if a Party relies on marketing approval granted by the U.S. Food and Drug Administration and if the Party grants approval within six months of an application for marketing approval, the five-year data

103 See Carlos Correa, Protecting Test Data for Pharmaceutical and Agrochemical Products under Free Trade Agreements, in Negotiating HeAlth: InTEllectual PROPERTY AND ACCESS To MEdicines (2006) (explaining that, under TRIPS, the reliance on prior reviewed data by a regulation authority to approve a generic version of the same drug need not be considered a "commercial use" of the data).

${ }^{104}$ See TPP-2 Art. 9.2(b) (stipulating that the drug regulatory authority may neither reference previously submitted clinical trial data nor rely on evidence that the product was previously approved either domestically or in another territory).

${ }^{105}$ See also KORUS Art. 18.9.2. 
exclusivity period begins when the drug was first approved in the U.S. ${ }^{106}$ Finally, the Peru and Colombia data exclusivity provisions provided for an express public health exception to data exclusivity allowing reference or reliance registration when either a compulsory licensing had been issued on the underlying patent(s) or even when there was no patent(s) if public health needs so required. All of these data exclusivity flexibilities are missing from the U.S. TPP-2 proposal.

Commentators are virtually unanimous in concluding that data exclusivity is not required by TRIPS Art. 39.3. Moreover, commentators express alarm that the adoption of data exclusivity would require a generic producer to reproduce clinical trial evidence in order to obtain marketing approval during the period of exclusivity. Not only would such evidence be duplicative, costly, and time-consuming, its collection would violate human subject protections in clinical trials, as trial participants would be required to submit to double-blind clinical trials even though evidence of efficacy and safety had been previously established.

\section{TPP-2 Art. [X] and Art. 9.3 - Mere Reference to the Doha Declaration, Public Health Protections}

The U.S. proposal mentions the Doha Declaration on the TRIPS Agreement and Public Health in TPP-2 Article [X] and Article 9.3. But the provisions fail to protect the core of the Doha Declaration's object - ensuring that all WTO members remain free to exercise "to the full" TRIPS flexibilities that promote access to affordable medicines for all. Notably, the provisions fail to incorporate the public health exceptions to data exclusivity and patent/registration linkage from the $2007 \mathrm{New}$ Trade Policy.

\section{TPP-2 Art. $[x] .1$}

Article $[\mathrm{X}] .1$ starts with the now standard affirmance of the Parties' prior commitment to the Doha Declaration. Although it is boilerplate to acknowledge a unanimous WTO commitment made nearly ten years ago, and although acknowledgement is superior to exclusion or rejection, the boilerplate does not make up for an absence of specific clarifying commitments about how countries can operationalize Doha to overcome the many TRIPS-plus provisions in the TPP proposal.

\footnotetext{
106 Free Trade Agreement between the United States of America and the Republic of Colombia, U.S.Colom., Art. 16.10.2(c), Nov. 22, 2006 [hereinafter U.S.-Colombia FTA], available at http:/www.ustr.gov/trade-agreements/free-trade-agreements/colombia-fta/final-text; Free Trade Agreement between the United States of America and the Republic of Peru, U.S.-Peru, Art. 16.10.2(c), Apr. 12, 2006 [hereinafter U.S.-Peru FTA], available at http://www.ustr.gov/trade-agreements/free-tradeagreements/peru-tpa/final-text. This early filing requirement applied only if Peru or Colombia granted marketing approval based in whole or in part on evidence of marketing approval in the U.S.
} 


\section{TPP-2 Art. [x].2}

Article [X].2 articulates Doha-related "understandings." Subsection (a) states that "The obligations of this Chapter do not and should not prevent a Party from taking measures to protect public health by promoting access to medicines for all, in particular concerning cases such as HIV/AIDS, tuberculosis, malaria, and other epidemics as well as circumstances of extreme urgency or national emergency."107 This statement has at least two problems.

First, it is important that any affirmation of the Doha Declaration not be limited to certain infectious disease epidemics and to a narrow subset of public health needs that can be classified as matters of extreme urgency or national emergency. The burden of non-communicable chronic diseases is escalating throughout the world, particularly in low- and middle-income countries where the cost of many chronic disease medicines, including those for cancers, psychiatric illnesses and other illnesses is too expensive for individual patients, insurers, and governments. ${ }^{108}$ Likewise, many developing countries face a persistent crisis with respect to neglected tropical diseases where newer, more expensive medicines might again be priced at unaffordable levels. ${ }^{109}$ The U.S.'s intent to purposefully exclude non-infectious chronic disease can be inferred from its efforts at the UN High Level Meeting on Non-Communicable Diseases to ensure that they were not described as an "epidemic" nor as an "emergency" and that no mention of the Doha Declaration appeared in the meeting's outcome. ${ }^{110}$

Second, the affirmation that the U.S. TPP proposals "do not" prevent a Party from taking measures to promote access to medicines may set a dangerous precedent for

107 TPP-2 Art. [X].2(a) (noting that subsection (a) ends with Doha-consistent boilerplate that the "[c]hapter can and should be interpreted and implemented in a manner supportive of each Party's right to protect public health and, in particular, to promote access to medicines for all.").

${ }^{108}$ See e.g. Felicia Marie Knaul, Julio Frenk \& Lawrence Shulman for the Global Task Force on Expanded Access to Cancer Care and Control in Developing Countries, Closing THE CANCER Divide: A BLUEPRINT TO EXPAND ACCESS IN LOW AND MIDDLE INCOME COUNTRIES, Section 7 (2011), available at http://ghsm.hms.harvard.edu/uploads/pdf/ccd report 111027.pdf.; World Health Organization, Non-Communicable Diseases: Country Profiles 2011, available at http://whqlibdoc.who.int/publications/2011/9789241502283_eng.pdf.

109 World Health Organization, Working to Overcome the Global ImPaCt of Neglected Tropical DISEASES, UPDATE 2011, available at http://www.who.int/neglected_diseases/2010report/WHO_NTD_report_update_2011.pdf.

110 William New, Questions Arise over UN Policy on Non-Communicable Diseases and IP Rights, IPWATcH (Sept. 16, 2011), available at http://www.ip-watch.org/weblog/2011/09/16/questionsarise-over-un-policy-on-non-communicable-diseases-and-ip-rights/. These efforts were ultimately successful, though there were two references to countries' need to use intellectual property flexibilities to access NCD medicines. See, Political Declaration of the High-level Meeting of the General Assembly on the Prevention and Control of Non-communicable Diseases, A/66/L1 (Sept. 19-20, 2011), available at http://www.un.org/en/ga/ncdmeeting2011/. 
the interpretation of the Doha Declaration. As described throughout this note, there are numerous TRIPS-plus standards in the TPP proposal that will predictably lead to higher prices and lower availability of pharmaceutical products, especially in developing countries. ${ }^{111}$ Implicitly defining these standards as compliant with the Doha Declaration significantly limits the express statement in the Declaration that TRIPS flexibilities can and should be available "to the full." Doha should be read to prevent the proposal or adoption of any TRIPS-plus measure that may negatively impact public health and access to medicines for all.112 A better provision fully embracing Doha would create an explicit and operational exception for any TPP provision on the basis that the member country concludes that the provision would impede access to affordable medicines or the promotion of public health objectives.

\section{TPP-2 Art. $[X] .2(b)$}

Article. [X].2(b) appears as an attempt to narrow the interpretation of TRIPS and Doha-compliant compulsory licenses into the procedurally labyrinth contours of what the U.S. calls the "TRIPS/Health solution." The TRIPS/Health solution is a current waiver and a proposal to amend the TRIPS agreement to allow export/import of medicines produced under special compulsory licenses to a country with little or no manufacturing capacity. ${ }^{113}$ The proposed TRIPS art. 31 bis

111 Chief among them may be: (1) lowered patent standards, presumptions of valid patent status, and express obligations to grant patents for new uses and new forms of existing products, (2) elimination of rights of pre-grant opposition, (3) extension of patent terms beyond the TRIPS requirement of 20 years to compensate for delays in granting patents and/or in granting marketing approval, (4) five-year data exclusivity following the first registration of a new pharmaceutical product with rights to evergreen data exclusivity for an additional three years whenever new clinical trial data is submitted, (5) mandatory patent/registration linkage giving patent holders a right to prevent registration of alleged patent infringing products no matter how weak the patent claim is, (6) unconscionable restrictions on government price control and therapeutic formulary policies, and (7) multiple TRIPS-plus enforcement measures.

112 TRIPS flexibilities thus include, for example, the adoption of strict patentability criteria under TRIPS Art. 27, the avoidance of patent extensions beyond 20 years in implementing TRIPS Art. 33, the avoidance of data exclusivity in the implementation of TRIPS Art. 39.3, and the avoidance of any other TRIPS-plus protection or enforcement measure that will increase market power of brand name pharmaceutical companies.

113 Paragraph 6 of the Doha Declaration required the development of a quick and expeditious mechanism allowing export/import of medicines to countries that had insufficient pharmaceutical capacity locally to either produce medicines that were not patented or those authorized pursuant to a properly issued compulsory license or government use order. Article 31(f) of the TRIPS Agreement had created a major barrier for these non-producing importers because it restricted the quantity of medicines produced pursuant to a compulsory license that could be exported to other countries to "non-predominant" amounts, presumably less than $50 \%$ of output. Unfortunately, the TRIPS/Health solution that was adopted on 30 August 2003 is painfully complex. See Frederick M. Abbott, The WTO Medicines Decision: World Pharmaceutical Trade and the Protection of Public Health, 99 AM. J. INT'L L 317 (2005). 
amendment on export licenses should not be called a "solution" to anything - it is labyrinth and virtually unworkable. ${ }^{114}$ It has been used only once, as a trial run between two countries that have not used it again. There is no evidence that the proposed TRIPS amendment will in fact promote global access to medicines, a fact articulated by Ecuador at the most recent TRIPS council meeting. ${ }^{115}$ Countries should maintain flexibilities to explore other options for meeting the particular challenges of supplying non-producing countries, including: (1) export of unlimited quantities through compulsory licenses issued on competition grounds (TRIPS Art. 31(k); (2) exporting non-predominant quantities pursuant to an ordinary TRIPS Art. 31 license; or (3) export to non-producing countries through an easy-to-use TRIPS Art. 30 limited exception.

\section{TPP-2 Art. 9.3}

TPP-2 Art. 9.3, which deals with "measures relating to certain regulated products," and more particularly with U.S. proposals for data exclusivity and patentregistration linkage, also contains boilerplate references to the Doha Declaration. ${ }^{116}$ The 2007 New Trade Policy, which led to revisions in the U.S.-Peru and U.S.-Colombia free trade agreements, provided express guidance on how to operationalize a text-based public health exception to data exclusivity and patent/registration linkage which is lacking from the current proposal. Specifically, TPP Art. 9.3 fails to provide for rights to override data exclusivity and patent/registration linkage either (1) to ensure rights to obtain marketing approval when a compulsory license or government use license is issued or (2) to have a compulsory-license-like exception to data exclusivity and patent/registration linkage even if no patent bar is in place.

\section{TPP-2 Art. 9.5 - Mandatory Adoption of Patent/Registration Linkage}

TPP-2 Art. 9.5 contains a TRIPS-plus proposal on what is called patent/registration linkage. Although patent/registration linkage is not mentioned in TRIPS and is not required in many countries, including most TPP negotiating

${ }^{114}$ Brook K. Baker, Arthritic Flexibilities for Accessing Medicines, Analysis of WTO Action Regarding Paragraph 6 of the Doha Declaration on the TRIPS Agreement and Public Health, 14 IND. INT'L \& ComP. L. REv. 613-715 (2004).

115 See TWN, Review of "Para 6" system, ACTA feature at TRIPS Council, SUNS \#7252 (2 November 2011), available at http://www.twnside.org.sg/title2/intellectual_property/info.service/2011/ipr.info.111101.htm

${ }^{116}$ See TPP-2 Art. 9.3 (reiterating that "a Party may take measures to protect public health in accordance with" the Doha Declaration, any current waiver (including presumably the TRIPS/Health solution) and any eventual amendment based on implementing the Doha Declaration (presumably referring indirectly to proposed amended Art. 31bis). 
countries, 117 it has become a common and contested feature of U.S. free trade agreements. ${ }^{118}$ Linking marketing approval to patent status gives patent owners a powerful and cost effective tool to block generic entry. Any company claiming a patent on a drug may halt the regulatory approval of a competing product without any private enforcement action and without a determination as to the validity of the underlying patent claim. This provides strong incentives for the filing of numerous, even if weak or invalid, patent claims which can then be used to halt marketing approval of potential competitors through the linkage system. Generics will then be required to wait until the completion of a patent challenge (for each claim) in order to reach the market, which may take many years. The costs of litigation and delay may be so high as to provide an effective deterrent to generic companies entering marketing with claimed patents - even where underlying patents are patently invalid.

TPP-2 goes even further than KORUS in specifying linkage requirements. TPP-2 proposes that its members be required to provide: (1) a transparent and effective mechanism to identify patent(s) covering an approved pharmaceutical product or its approved method of use; (2) notice to a patent holder of the identity of another person who intends to market the same and "similar" products during the term of the identified patent or patents; (3) automatic stays of marketing approval activity for the follow-on product sufficient to allow an opportunity to adjudicate disputes concerning patent validity or infringement; (4) expeditious judicial or administrative procedures to allow timely adjudication of patent disputes, including rights to issue provisional orders; and (5) for the denial of registration for infringing products for the duration of the patent. On the other hand, consistent with U.S. law, where a challenged party successfully challenges the validity or applicability of the patent, it is required to be provided with an effective reward, which might include a period of marketing exclusivity.

Patent/registration linkage turns drug regulatory authorities into patent policing agents who aid patent holders in the enforcement of their private rights. Moreover the automatic stays can be abusive. In response to the experience of the

117 See Public Citizen \& HEAlth GAP (explaining that "Vietnamese law contains no provision that links the patent system to the drug marketing approval process" and that many U.S. FTAs require patent linkage which "shifts burdens of early patent enforcement to drug regulatory authorities."); see also Public Citizen TPP-Malaysian Law Comparison (noting that "Malaysian law contains no provision that links the patent system to marketing approval process."); $c f$. Public Citizen TPPAustralian Law Comparison (explaining that although "AUSFTA introduced patent linkage in Australia, Australia sought to limit its effect through statutory measures imposing penalties for linkage evergreening" and subsequently, the USTR attacked these safeguards and therefore, the TPP proposal "raises a serious concern that the [U.S.] may seek to limit or eliminate Australian safeguards.").

118 See KORUS Art. 18.9.5. 
use of linkage to evergreen patents through the filing of subsequent (often invalid) claims to halt generic entry, U.S. law now limits patent holders to one automatic stay to litigate any patent claims. ${ }^{119}$ Furthermore, there are still concerns that strict forms of patent/registration linkage might interfere with effective use of compulsory licenses. This is because licensees could be prevented from marketing their generic equivalents after receiving a license on some patent claims by virtue of subsequent claims being filed on the same product.

\section{E. TPP-2 Arts. 9.4, 9.6, 9.7, and 9.8 - TEAM Access Window Mainly Benefits Innovator Registration}

Well before the new leak of TPP-2, the U.S. released its Trade-Enhancing Access to Medicines proposal (TEAM Access Window). ${ }^{120}$ The memo stated that the Access Window was "designed to deploy the tools of trade policy to promote trade in, and reduce obstacles to, access to both innovative and generic medicines, while supporting the innovation and intellectual property protection that is vital to developing new medicines and achieving other medical breakthroughs." The memo immediately became the subject of criticism for both its obscuration of substance and its non-transparent process by public health advocates. ${ }^{121}$ Now that the actual text of the Access Window has been leaked, it is clear that its main impact will be to ease registration for innovators with no real benefit for access to generics.

As discussed above, the general rule under TPP-2 is that members must grant patent extension for regulatory delays, 5/3-year data exclusivity, and patent/registration linkage. These requirements will apply to the vast majority of marketing requests where the Access Window does not apply either because a country has not changed its law to utilize Access Window provisions (see discussion below) or because the marketing-approval applicant has chosen not to utilize the Access Window mechanism. ${ }^{122}$

The U.S. Access Window provides countries with the option of having marketing approval procedures that rely in whole or in part on the fact of marketing approval/registration in another country. ${ }^{123}$ If countries have such a fast-track,

11921 U.S.C. 355(j)(2) and (5).

120 See Trans-Pacific Partnership Trade Goals to Enhance Access to Medicines, USTR, available at http://www.ustr.gov/webfm_send/3059.

121 http://www.citizenstrade.org/ctc/blog/2011/10/22/leaked-trans-pacific-fta-texts-reveal-us-undermining-access-to-medicine/

122 TPP-2 art. 9.8(b) confirms that "a Party may not refuse to grant approval of a new pharmaceutical product on the basis of a failure of an applicant for marketing approval to satisfy the [Access Window] requirements of subparagraphs 6(e) of Article 8 or paragraph 4 and 6 of this Article."

${ }^{123}$ See TPP-2 arts. 9.4, 9.6, 8-6(e) (noting that countries are not required to create the TEAM Access Window, but they "may" do so in a narrow subset of cases - where the party "requires or permits an applicant to obtain approval for marketing a new pharmaceutical product in its territory by relying, in whole or in part, on the prior approval of the pharmaceutical product by the regulatory 
reliance mechanism, they can limit patent term extensions related to regulatory delays (not patenting delays), ${ }^{124}$ data protection, and patent/registration linkage for applicants who use the reliance mechanism within an unspecified number of years the "access window."125 If the reliance registrant delays filing a reliance-application until after the access window, the applicant loses rights to these three, TRIPS-plus, registration-related IP benefits.

It is important to remember that the applicant would always have the option to apply for marketing approval by submitting a full registration dossier that does not rely in whole or in part on the fact or prior registration elsewhere. The silver lining for pharmaceutical companies, even where the Access Window does apply, is contained in Article 9.8(a), which requires the TPP country to allow initiation of marketing registration in that country based on any information available to the applicant, including "evidence of prior approval of the product in another Party [country]." This easy-to-meet standard makes it easier to file early for marketing approval, but it does not necessarily ensure quicker final approval of drugs. More importantly, speedier registration will not necessarily result in lower prices generics will still have to wait until patent terms and/or data exclusivity periods expire.

Pharmaceutical companies have long chaffed over the lack of harmonization of drug regulatory authorities' marketing approval requirements, standards, and processes. The multinational pharmaceutical industry would like a registration process that is very like what is provided by the WIPO Patent Cooperation Treaty, an easy-to-use, standardized mechanism to initiate marketing approval applications before national drug regulatory authorities. Indeed, there is a separate annex on pharmaceutical regulatory harmonization in the US TPP proposals. ${ }^{126}$ Article 9.8(a) provides the industry with the easy-to-use, fast-track mechanism it has desired. Moreover, pharmaceutical companies can even choose which information and format they want to submit as applicants do not have to submit complete dossiers in order to cross the start-line for the Access Window. ${ }^{127}$

authority in another county.").

${ }^{124}$ See TPP-2 art. 8.6(e) (applying Access Window restrictions only with respect to art. 8.6(c) extensions - those caused by unreasonable delays in the marketing approval process).

125 See TPP-2 FN 2 (claiming that the length of the TEAM Access Window should enhance certainty, provide incentive for the diffusion of pharmaceutical products, respect commercial consideration, and account for challenges faced by smaller or lesser experienced applicants or the time needed to assess country-specific safety and efficacy issues).

126 See Trans-Pacific Partnership, U.S. Introduction to Proposed TBT Annexes on Medical Devices, Pharmaceutical Products and Cosmetic Products [hereinafter TPP U.S. Intro to TBT Annexes], available at http://www.bilaterals.org/IMG/pdf_TransPacificTBTwMedicalAnnexes.pdf (extending the industry's intentions and interests); Trans-Pacific Partnership, U.S. Textual Proposal for the TBT Chapter: Annex on Phamaceutical Products, Annex IV [hereinafter TPP Annex IV], available at http://www.bilaterals.org/IMG/pdf_TransPacificTBTwMedicalAnnexes.pdf (noting that in paras. 8 and 9, the U.S. seeks TPP partners' agreement to use the ICD Common Technical Document as the standardized harmonized form to initiate marketing approval requests.)

127 TPP-2 article 9-8 (providing that "[w] here a party chooses to apply subparagraph 6(e) of Article 8 and paragraphs 4 and 6 of this Article [Article 9], the following provisions shall apply: (a) a 
Based on having satisfied minimal Access-Window information and timing prerequisites, right-holders will potentially be entitled to multi-year patent-term extensions for marketing approval delays, to successive data exclusivity periods that will run from the time final marketing approval (not from the time of the simplified initiation of the registration request), and patent-registration linkage -- all without benefit of the flexibilities called for in the 2007 New Trade Deal.128

TPP-2 Art. 9.7 contains another new-to-U.S. FTAs provision encouraging even longer periods of data exclusivity. The provision states that parties would be exempted from the three-year data protection terms for submission of new clinical information, automatic delays of marketing approval in their patent/registration linkage mechanisms, and rewards for successful challenges to patent rights if they adopt periods of data exclusivity for new pharmaceutical products for an undefined duration ("Y") in excess of five years. If pharmaceutical companies can get substantially longer data exclusivity, especially if it contains mechanisms for evergreening exclusivity such as that involving biologics, they won't have to rely on patent protections to obtain marketing monopolies. Data monopolies of sufficient length will be superior to patents from the perspective of pharmaceutical firms because data monopolies give the same or higher level of monopoly protection without the need and expenses of proving that a product meets the relatively high standards for patentability.

Party shall permit an applicant to commence the process of obtaining marketing approval by providing the regulatory authority of the Party information supporting approval of the new pharmaceutical product in the Party that is available to the person at the time the request is made, such as evidence of the prior approval of the product in another Party. It is understood, that, while a Party may impose reasonable additional requirements or deadlines as a condition of authorizing the person to market to market the pharmaceutical product in its territory, satisfaction of those additional requirements or deadlines or the granting of approval shall be recognized by the Party as necessarily occurring after the commencement of the marketing approval process within the meaning of subparagraph 6(e) of Article 8 or paragraphs 4 and 6 of this Article.") (emphasis added).

128 The problem is not simply making a big deal out of very minor process, the Access Window provisions are also likely to result in pressure from the US and Big Pharma for what is essentially a harmonized global registration system, such as those proposed in the Proposed TBT Chapter Annex on Pharmaceutical Products. We can now see that US is arguing with trade partners that they should vicariously grant registration in their countries based on prior marketing approval by drug regulators in the US, Europe, or Japan. If countries are tempted to adopt full-scale reliance registration, there is a risk that they will have reduced ability to assess medicines in light of the particular patient risks and benefits in their country. Although reliance registration may have certain advantages for countries with weak regulatory authorities and although lack of procedural harmonization adversely impacts both innovator companies and generics, countries are being asked to give up far too much TRIPS-plus territory for a quick-registration Access Window that doesn't require fast completion and prosecution of registration applications and that results in greater and longer monopoly protections that will inevitably lead to higher prices and reduced generic competition. 
Admittedly, there is some potential benefit to countries that want to provide inducements to pharmaceutical companies to bring their new medicines to market more quickly. To the extent that differential registration standards and processes have disincentivized innovators from quickly launching new products, simplification might speed up market entry. Drug regulatory systems should be made more transparent, efficient, and even harmonized, but only so long as high, countryspecific standards for assuring quality, safety, and efficacy are maintained. The desirability of earlier product introduction should have nothing to do with a tradeoff involving greater IP protections that extend and strengthen drug company patent and data-related monopolies. The Access Window is promoted as benefitting TPP parties, but it is clear that the true beneficiaries are innovator companies. ${ }^{129}$

\section{General Obligations Relating to Enforcement}

Art. 10.2 requires presumptions in civil and administrative proceedings that "the person whose name is indicated in the usual manner as the author, producer, performer, or publisher of the work, performance, or phonogram is the designated right holder" and that "the copyright or related right subsists in such subject matter." Neither of these presumptions exist in current U.S. law. ${ }^{130}$

\section{CiVIL ANd Administrative Procedures ANd Remedies}

\section{A. Art. 12.2 - Injunctions}

TPP Art. 12.2 requires every party to provide for injunctive relief, similar to ACTA Art. 8.1.131 However, unlike ACTA, TPP Art. 12.2 beneficially narrows the

129 The problem is not simply making a big deal out of very minor process, the Access Window provisions are also likely to result in pressure from the US and Big Pharma for what is essentially a harmonized global registration system, such as those proposed in the Proposed TBT Chapter Annex on Pharmaceutical Products. We can now see that US is arguing with trade partners that they should vicariously grant registration in their countries based on prior marketing approval by drug regulators in the US, Europe, or Japan. If countries are tempted to adopt full-scale reliance registration, there is a risk that they will have reduced ability to assess medicines in light of the particular patient risks and benefits in their country. Although reliance registration may have certain advantages for countries with weak regulatory authorities and although lack of procedural harmonization adversely impacts both innovator companies and generics, countries are being asked to give up far too much TRIPS-plus territory for a quick-registration Access Window that doesn't require fast completion and prosecution of registration applications and that results in greater and longer monopoly protections that will inevitably lead to higher prices and reduced generic competition.

130 See Jodie Griffin, Inconsistencies Between the Trans-Pacific Partnership (TPP) Agreement and US Law, Public Knowledge, www.publicknowledge.org/files/TPP\%20Analysis.pdf (noting that fulfillment of notice provisions in U.S. law "only affects a defendant's claim of innocent infringement").

${ }^{131}$ ACTA Art. 8.1 (noting that "[e]ach Party shall provide that, in civil judicial proceedings concerning the enforcement of intellectual property rights, its judicial authorities have the authority 
scope of injunctions by providing that injunctive relief has to be consistent with the safeguards contained in Art. 44 of TRIPS. ${ }^{132}$ Also unlike ACTA, the injunctive relief does not extend to third parties. Overall, the injunction section in the TPP proposal seems to be a watered down version of the ACTA standards. This provision on injunctive relief was not included in KORUS, which did not require injunctions to prevent the exportation of infringing goods.

\section{B. Art. 12.3 - Damages}

TPP Art. 12.3 mandates that determinations of damages for copyright infringement and trademark counterfeiting exceed the amount judged to be "adequate to compensate for the injury the right holder has suffered." On top of such compensatory damages, the TPP proposal mandates damages equal to "the profits of the infringer that are attributable to the infringement." In addition, the provision would require that "judicial authorities shall consider, inter alia, the value of the infringed good or service, measured by the suggested retail price or other legitimate measure of value submitted by the right holder." These provisions do not have a clear analogue in U.S. law. ${ }^{133}$

A key problem with these compensation-plus measures is that they ignore the phenomenon of exclusionary pricing, particularly in developing countries. Imagine, for example, the common case of a copyrighted music supplier that charges the

to issue an order against a party to desist from an infringement, and inter alia, an order to that party or, where appropriate, to a third party over whom the relevant judicial authority exercises jurisdiction, to prevent goods that involve the infringement of an intellectual property right from entering into the channels of commerce.").

132 TRIPS Art. 44 (enumerating that "1. The judicial authorities shall have the authority to order a party to desist from an infringement, inter alia to prevent the entry into the channels of commerce in their jurisdiction of imported goods that involve the infringement of an intellectual property right, immediately after customs clearance of such goods. Members are not obliged to accord such authority in respect of protected subject matter acquired or ordered by a person prior to knowing or having reasonable grounds to know that dealing in such subject matter would entail the infringement of an intellectual property right. 2. Notwithstanding the other provisions of this Part and provided that the provisions of Part II specifically addressing use by governments, or by third parties authorized by a government, without the authorization of the right holder are complied with, Members may limit the remedies available against such use to payment of remuneration in accordance with subparagraph (h) of Article 31. In other cases, the remedies under this Part shall apply or, where these remedies are inconsistent with a Member's law, declaratory judgments and adequate compensation shall be available.").

${ }^{133}$ Jodie Griffin, Inconsistencies Between the Trans-Pacific Partnership (TPP) Agreement and US Law, Public Knowledge, www.publicknowledge.org/files/TPP\%20Analysis.pdf (contrasting the TPP proposal with sec. 504(b) of the Copyright Act and the willing buyer, willing seller standard of Frank Music Corp. v. MGM Inc.). 
same price in a poor country as in the U.S. - e.g. $\$ 17$ for a music CD. ${ }^{134}$ What should be the measure of damages for the infringing the copyright of that CD through the making of illegal copies? A reasonable compensatory damage measure may be based on the percentage of the high price market (those willing and able to pay \$17) that are taken away by infringement. But this measure - the true measure of harm to the copyright owner who has chosen to excessively price a product - would be far lower than the two measures suggested by TPP because very few people in poor countries are willing or able to pay U.S.-level prices for media or other protected goods. Multiplying the number of copies made the "retail price" (\$17 in our example) would over-compensate the rights holder for sales that would have never taken place at that price. ${ }^{135}$

TPP members should retain their sovereign rights to develop measures of damages appropriate for their own social and economic contexts. This is particularly important in developing countries where the impact of excessive pricing is likely to be most pronounced. ${ }^{136}$

There are some key differences in the TPP proposals and other IP chapters in trade agreements.

- Unlike ACTA Art. $9.1^{137}$ and TRIPS Art. 45(1), TPP Art. 12.3 does not require the infringer to "knowingly or with reasonable grounds to know, engage in infringing activity," thus converting the liability standard to one

134 This experience is studies in some detail in MEdia PiraCy In EMERGing EConomies (SSRC 2011).

135 See Public Citizen \& Health GAP (noting that "the U.S. proposal [which] would require courts to consider suggested retail price or other measure of value submitted by the right holder ... strongly favors the interests of the right holders" since the hypothetical suggested retail price "may turn out to be inflated or otherwise inaccurate"); Public Citizen TPP-Malaysian Law Comparison (commenting that the TPP proposal "would lead to an unrealistic determination of damages, which would empower rights holders in court settlements and discourage defendants from litigating cases" and that "Malaysian courts can better balance the competing interests ... by maintaining the compensatory approach to damages, filtering claims and continuing to determine appropriate calculations for damages case-by-case.").

136 Sean Flynn, Aidan Hollis \& Michael Palmedo, An Economic Argument for Open Access to Medicine Patents in Developing Countries, 37 J.L. Med. \& Ethics 184 (2009).

${ }^{137}$ ACTA Art. 9.1 (providing that "[e]ach Party shall provide that, in civil judicial proceedings concerning the enforcement of intellectual property rights, its judicial authorities have the authority to order the infringer who, knowingly or with reasonable grounds to know, engaged in infringing activity to pay the right holder damages adequate to compensate for the injury the right holder has suffered as a result of the infringement. In determining the amount of damages for infringement of intellectual property rights, a Party's judicial authorities shall have the authority to consider, inter alia, any legitimate measure of value the right holder submits, which may include lost profits, the value of the infringed goods or services measured by the market price, or the suggested retail price."). 
of strict liability.

- Compared to KORUS, TPP Art. 12.3 uses "and" to require payment of both compensatory damages and lost profits, while KORUS Art. 18.10.5 requires either of the two, but not both, using "or".

- There is also a rewritten definition in Art. $12.3 \mathrm{fn} \mathrm{17,} \mathrm{of} \mathrm{"exclusive}$ licensee," stating that it shall "include" the exclusive licensee of any one of exclusive rights encompassed in a given intellectual property right. It is unclear why the definition is not bound more specifically.

\section{Art. 12.4 - Pre-Established Damages}

TPP Art. 12.4 further mandates damages in excess of compensatory levels by requiring a system of pre-established damages "sufficiently high to constitute a deterrent to future infringement."138 In a standard that reaches beyond any international intellectual property agreement signed by any country, TPP Art. 12.4 further provides that in patent infringement cases, the damages may be increased up to three times the amount found or assessed.

U.S. law provides for statutory damages for copyright violations, but does not require that such damages be sufficiently high to constitute a deterrent to future infringements. 139 Normally, civil law damages for violation of private rights, including rights to contract and property, are to compensate, not deter. Deterrentlevel penalties, by definition, create inefficient exchanges in the market, threatening competition. The opposite of deterrent damages are liability rules that allow use of protected matter in exchange for compensatory damages. Such standards promote rather than retard competition.

Pre-established, or "statutory," damages for copyright infringement are not recognized in every major copyright system, and there are increasing criticisms of the very high statutory damages in current U.S. law. ${ }^{140}$ In ACTA, pre-established damages were not required. Parties were given the choice between pre-established damages, presumptions for determining the amount of damages, or "additional"

${ }^{138}$ TPP Art. 12.4.

139 Jodie Griffin, Inconsistencies Between the Trans-Pacific Partnership (TPP) Agreement and US Law, Public Knowledge, www.publicknowledge.org/files/TPP\%20Analysis.pdf (citing Sec. 504(b) of the U.S. Copyright Act).

${ }^{140}$ See Pamela Samuelson \& Tara Wheatland, Statutory Damages in Copyright Law: A Remedy in Need of Reform, 51 WM. \& MARY L. REV. 439, 441 (2009) (explaining that the U.S. is "an outlier in the global copyright community in giving plaintiffs in copyright cases the ability to elect, at any time before final judgment.”). 
copyright damages. ${ }^{141}$

The proposed triple damages scheme for patent violations is extreme and untested. U.S. law contains the possibility for treble damages for willful patent infringement. But TPP's standard does not confine its requirement to such cases. This is an extremely dangerous provision that could award windfalls to patent owners, thus encouraging strategic patent filings and litigation for rent seeking.

\section{Art. 12.5-Attorney's fees}

TPP makes the payment of attorney's fees by the losing party as the norm in civil judicial proceedings. ACTA Art. 9.5 requires that for at least copyright and trademark infringement, the prevailing party "where appropriate" may be awarded payment of court costs or fees and appropriate attorney's fees, "or any other expenses as provided for under that Party's law." TPP Art. 12.5 makes awarding of such fees the norm "except in exceptional circumstances," and doesn't leave flexibility for parties to determine whether alternate expenses get paid instead of attorney's fees. TPP Art. 12.5 also applies court costs or fees to patent infringement as well, and attorney's fees in patent infringement "at least in exceptional circumstances."

\section{E. Art. 12.7 - Remedies}

TPP mandates a very pro-enforcement regime of remedies against goods that have been found to be pirated or counterfeit, which sets destruction of the goods as the norm. TPP Arts. 12.7(a), (b), and (c) are respectively equivalent to ACTA Arts. $10.1^{142}, 10.2^{143}$, and 20.2.144 TPP Art. 12.7(b) goes beyond TRIPS and ACTA by removing the requirement that destroyed goods have been predominantly used in manufacture or creation of infringing goods. The provision also goes beyond current U.S. law by requiring that a broader array of "materials and implements" be

141 See ACTA Art. 9.3.

${ }^{142}$ ACTA Art. 10.1 (providing that "[a]t least with respect to pirated copyright goods and counterfeit trademark goods, each Party shall provide that, in civil judicial proceedings, at the right holder's request, its judicial authorities have the authority to order that such infringing goods be destroyed, except in exceptional circumstances, without compensation of any sort.").

${ }^{143}$ ACTA Art. 10.2 (enumerating that "[e]ach Party shall further provide that its judicial authorities have the authority to order that materials and implements, the predominant use of which has been in the manufacture or creation of such infringing goods, be, without undue delay and without compensation of any sort, destroyed or disposed of outside the channels of commerce in such a manner as to minimize the risks of further infringements.").

${ }^{144}$ ACTA at Art. 20.2 (stating that "[i]n regard to counterfeit trademark goods, the simple removal of the trademark unlawfully affixed shall not be sufficient, other than in exceptional cases, to permit release of the goods into the channels of commerce."). 
destroyed than is the case under sec. 503(b) of the Copyright Act. ${ }^{145}$

In regards to counterfeit trademarked goods, unlike ACTA Art. 20.2, TPP Art. 12.7(c) does not allow for the removal of the trademark and release of the goods outside of the market in exceptional cases - e.g. as donations to public and charity programs. This could have particularly troublesome impacts on access to medicines - potentially requiring destruction of safe and effective medicines that could be used elsewhere.

\section{F. Art. 12.8 - Information Related to Infringement}

TPP Art. 12.8 requires that judicial authorities have authority order to "the infringer" to provide the rights holder with various information, including "regarding any persons or entities involved in any aspect of the infringement and regarding the means of production or distribution channel of such goods or services, including the identification of third persons involved in the production and distribution of the infringing goods or services." Unlike ACTA, this proposal lacks safeguards requiring that any divulging of information be without prejudice to domestic laws governing privileges, the protection of confidential information sources or the processing of personal data. ${ }^{146}$ Furthermore, TPP does not require that access to such information to be conditional "upon a justified request of the right holder." Concerns have been raised that the provision is not consistent with evidentiary privileges in U.S. law, including state law privileges and the Federal Rules of Evidence. 147

\section{G. Art. 12.9 - Additional Punishments}

TPP Art. 12.9 goes beyond the purview of intellectual property rights

145 See Jodie Griffin, Inconsistencies Between the Trans-Pacific Partnership (TPP) Agreement and US Law, Public Knowledge, www.publicknowledge.org/files/TPP\%20Analysis.pdf

${ }^{146}$ ACTA Art. 11 (requiring that " $[\mathrm{w}]$ ithout prejudice to its law governing privilege, the protection of confidentiality of information sources, or the processing of personal data, each Party shall provide that, in civil judicial proceedings concerning the enforcement of intellectual property rights, its judicial authorities have the authority, upon a justified request of the right holder, to order the infringer or, in the alternative, the alleged infringer, to provide to the right holder or to the judicial authorities, at least for the purpose of collecting evidence, relevant information as provided for in its applicable laws and regulations that the infringer or alleged infringer possesses or controls. Such information may include information regarding any person involved in any aspect of the infringement or alleged infringement and regarding the means of production or the channels of distribution of the infringing or allegedly infringing goods or services, including the identification of third persons alleged to be involved in the production and distribution of such goods or services and of their channels of distribution.").

${ }^{147}$ See Jodie Griffin, Inconsistencies Between the Trans-Pacific Partnership (TPP) Agreement and US Law, Public Knowledge, www.publicknowledge.org/files/TPP\%20Analysis.pdf 
enforcement and reaches into the subject matter of contempt of court. Mimicking KORUS Art. 18.10.11, TPP Art. 12.9(a) allows fines and imprisonment as means of punishing those who fail to abide by valid orders issued by judicial authorities. Additionally, 12.9(b) allows sanctions against "counsel, experts, or other persons subject to the court's jurisdiction" for violating "judicial orders regarding the protection of confidential information produced or exchanged in a proceeding."148

\section{Provisional Measures}

\section{A. Art. 13.1 - Provisional Relief Inaudita Altera Parte}

TPP increases requirements to grant injunctions inaudita altera parte, i.e. without prior hearing of the other side (also known as ex parte). TPP Art. 13.1 requires that such requests generally be processed by judicial authorities within ten days. Unlike ACTA Art. $12.2^{149}$ and KORUS Art. 18.10.17,150 TPP does not require a showing that "delay is likely to cause irreparable harm" or "a demonstrable risk of evidence being destroyed" to adopt provisional measures inaudita altera parte.

U.S. law does not contain any requirement that preliminary injunction requests be granted within 10 days. Nor does the TPP proposal export the standards in U.S. law that make preliminary injunctions, and especially ex parte preliminary injunctions, difficult to obtain s a matter of course. ${ }^{151}$

\section{Special ReQuirements Related to Border Enforcement}

\section{A. Art. 14.4-Ex Officio Authority}

Similar to ACTA Art. 16, and in excess of TRIPS, the TPP proposal grants ex officio authority to customs officials to seize goods "suspected of being counterfeit or confusingly similar trademark goods, or pirated copyright goods." 152 Such ex officio authority extends to imported, exported, and in-transit merchandise.

148 TPP Art. $12.9(\mathrm{~b})$.

${ }^{149}$ Id. at Art. 12.2 (mandating that "[e]ach Party shall provide that its judicial authorities have the authority to adopt provisional measures inaudita altera parte where appropriate, in particular where any delay is likely to cause irreparable harm to the right holder, or where there is a demonstrable risk of evidence being destroyed. In proceedings conducted inaudita altera parte, each Party shall provide its judicial authorities with the authority to act expeditiously on requests for provisional measures and to make a decision without undue delay.").

${ }^{150}$ KORUS Art. 18.10 .17 (requiring that "[e]ach Party shall act on requests for provisional measures inaudita altera parte expeditiously").

${ }^{151}$ See Jodie Griffin, Inconsistencies Between the Trans-Pacific Partnership (TPP) Agreement and US Law, Public Knowledge, www.publicknowledge.org/files/TPP\%20Analysis.pdf

${ }^{152}$ Id. 
The standard for a seizure being based on mere suspicion of being "confusingly similar" is an extraordinarily low threshold for blocking the free trade of goods. Nearly every generic medicine or generic version of a trademarked good (e.g. the supermarket brand) is likely to have a label that could be suspected of being confusingly similar to the originator, even thought the label does not in fact violate any trademark right. 153

Although TPP excludes patents from the purview of the border measures provisions, this fails to assuage the concerns over its effects on access to medicines. ${ }^{154}$ In 2009, a shipment of generic medicine amoxicillin, which is the INN name required to be on the label, was seized in-transit by German customs officials due to the suspicion that it was confusingly similar to trademarked brand name drug called "Amoxil." 155 As a result, the cargo was detained for weeks until it was determined that there was no trademark infringement.

\section{B. FN 20 - Definitions of Counterfeit Trademark Goods \& Pirated Copyright Goods}

Unlike ACTA, TPP's definitions of counterfeit trademark goods and pirated copyright goods provide a safeguard against application of the law of in-transit countries. TPP's definition of counterfeit trademark goods concern the infringement of the "rights of the owner of the trademark in question under law of the country of importation" while ACTA's definition concerns the rights of the owner under the law of the country in which the procedures are invoked. ${ }^{156}$ Similarly, TPP's definition of pirated copyright goods concerns infringement of a copyright under the law of the country of importation while ACTA's definition concerns the law of the country in which the procedures are invoked. ${ }^{157}$

153 See PIJIP, Counterfeit vs. Confusingly Similar Products, www.wcl.american.edu/pijip/go/pdf05072010

${ }^{154}$ See Public Citizen TPP-Malaysian Law Comparison (explaining that the U.S. TPP proposal would broader then scope of ex officio authority to cover civil trademark infringement cases and therefore, it will contribute to the risk of "wrongly detaining generic medicines, which may usefully communicate their bioequivalence to consumers through similar packaging.").

${ }^{155}$ Christian Wagner-Ahlfs, Seizure of Indian generic amoxicillin in Frankfurt, EsSENTIALDRUGS.ORG, available at http://www.essentialdrugs.org/edrug/archive/200906/msg00014.php.

${ }^{156}$ ACTA Art. 5(d) (defining that "counterfeit trademark goods means any goods, including packaging, bearing without authorization a trademark which is identical to the trademark validly registered in respect of such goods, or which cannot be distinguished in its essential aspects from such a trademark, and which thereby infringes the rights of the owner of the trademark in question under the law of the country in which the procedures set forth in Chapter II (Legal Framework for Enforcement of Intellectual Property Rights) are Invoked.").

${ }^{157} I$ d. at Art. 5(k) (stating that "pirated copyright goods means any goods which are copies made without the consent of the right holder or person duly authorized by the right holder in the country of production and which are made directly or indirectly from an article where the making of 


\section{Art. 14.6-Remedies}

TPP mandates a pro-enforcement border enforcement regime, which sets destruction of the goods as the norm. TPP Art. 14.6 is equivalent to ACTA Arts. 20.1 and 20.2. ${ }^{158}$ Although both TPP and ACTA provide for an exception to destruction of the infringing goods as a form of remedy, TPP does not allow for the option of disposal of such goods outside the channels of commerce.

\section{Art. 14.8 - Small Consignments}

This provision resembles ACTA's restriction of the application of the TRIPS provision allowing "de minimis" shipments of goods to be exempted from border search and seizure provisions. TPP Art. 14.8 is essentially identical to ACTA Art. $14,{ }^{159}$ which eliminates the TRIPS Art. 60 exception for small quantities of goods of a sent in small consignments.

\section{Criminal Enforcement - Offences}

\section{A. Art. 15.1-Offenses}

TPP Art. 15.1 would expand internationally required criminalization of copyright infringement to include "infringements that have no direct or indirect motivation of financial gain."

TRIPS only requires criminalization of counterfeiting or copyright piracy is "willful" and "on a commercial scale". ${ }^{160}$ In the U.S.-China case, the WTO affirmed that countries may implement their own definition of "commercial scale," including both qualitative (e.g. for profit) and quantitative measures for the term. TPP Art. 15.1 shifts the potential focus to individual end-users by defining "commercial scale"

that copy would have constituted an infringement of a copyright or a related right under the law of the country in which the procedures set forth in Chapter II (Legal Framework for Enforcement of Intellectual Property Rights) are invoked.").

${ }^{158}$ Id. at Arts. 20.1, 20.2 (providing that "[e]ach Party shall provide that its competent authorities have the authority to order the destruction of goods following a determination referred to in Article 19 (Determination as to Infringement) that the goods are infringing. In cases where such goods are not destroyed, each Party shall ensure that, except in exceptional circumstances, such goods are disposed of outside the channels of commerce in such a manner as to avoid any harm to the right holder. 2. In regard to counterfeit trademark goods, the simple removal of the trademark unlawfully affixed shall not be sufficient, other than in exceptional cases, to permit release of the goods into the channels of commerce.").

${ }^{159} I d$. at Art. 14 (enumerating that "1. Each Party shall include in the application of this Section goods of a commercial nature sent in small consignments. 2. A Party may exclude from the application of this Section small quantities of goods of a non-commercial nature contained in travellers' personal luggage.").

160 TRIPS Art. 61. 
as including (a) "significant willful copyright or related rights infringements with no direct or indirect motivation of financial gain," and (b) willful infringements for purposes of "private financial gain." Footnote 24 further defines "private financial gain" to include the mere "receipt or expectation of anything of value." Under these definitions, it appears that any knowing receipt of copyright infringing material on the internet or otherwise could be defined as a violation of criminal law.

This provision does not track the details of current U.S. domestic law. U.S. law does not contain this definition of "private financial gain." 161 And U.S. law contains what might be seen as a floor on the term "significant," limiting criminal infringement to willful infringement of at least $\$ 1,000$ worth of material in a 180day period. ${ }^{162}$

Normally, the responsibility for enforcing IP infringements lies with the right holder. By making the infringement criminal, the duty, cost and decision on whether to enforce the right shift to the state. The TPP proposal would greatly expand the amount of infringement activity subject to state enforcement. In addition to resource concerns, this expansion of criminal liability raises civil liberty concerns about state selection and enforcement of law infringement that is likely to be ubiquitous in many countries. ${ }^{163}$

The provision conflicts with Art. 17.11.22 of the U.S.-Chile free trade agreement. That agreement criminalizes willful infringement for "commercial advantage or financial gain," rather than "private" financial gain, and contains a footnote 33, explaining that "evidence of reproduction or distribution of a copyrighted work, by itself, shall not be sufficient to establish willful infringement."

\section{B. Art. 15.2-Offenses}

TPP Art. 15.2 expands criminal liability for acts "even absent willful trademark counterfeiting or copyright or related rights piracy." The proposed extension of criminal liability would include any "knowing trafficking in" labels or packaging "to which a counterfeit trademark has been applied" or "counterfeit or illicit labels" have been affixed to (in the case of specific products). These are new criminal provisions that extend beyond TRIPS and ACTA. ${ }^{164}$ Unlike ACTA, TPP does not

16117 U.S.C. $§ 506$.

162 See Jodie Griffin, Inconsistencies Between the Trans-Pacific Partnership (TPP) Agreement and US Law, Public Knowledge, www.publicknowledge.org/files/TPP\%20Analysis.pdf

163 See New York Times, Russia Uses Microsoft to Suppress Dissent, (Sept 11, 2010).

${ }^{164}$ ACTA Art. 23.2 (requiring that "[e]ach Party shall provide for criminal procedures and penalties to be applied in cases of willful importation and domestic use, in the course of trade and on a commercial scale, of labels or packaging: (a) to which a mark has been applied without authorization which is identical to, or cannot be distinguished from, a trademark registered in its territory; and (b) which are intended to be used in the course of trade on goods or in relation to services which are identical to goods or services for which such trademark is registered."). 
require the use of the "confusing" label "on goods or in relation to services which are identical to goods or services for which such trademark is registered."

\section{Art. 15.4-Offenses}

TPP Art. 15.4 criminalizes aiding and abetting infringement. This is likely to be meant for online intermediaries, as discussed further in XII, below.

\section{CRIMINAL ENFORCEMENT}

\section{A. Art. 15.5(a) - Penalties}

TPP Art. 15.5(a) mandates that criminal penalties follow guidelines that are not included in present U.S. law. The provision, modeled on KORUS and ACTA, ${ }^{165}$ would require that criminal penalties include "sentences of imprisonment as well as monetary fines sufficiently high to provide a deterrent to future infringements, consistent with a policy of removing the infringer's monetary incentive." The provision further requires "policies or guidelines that encourage judicial authorities to impose those penalties at levels sufficient to provide a deterrent to future infringements." Neither of these standards are reflected in current U.S. sentencing guidelines for copyright infringement. ${ }^{166}$

Both TPP and ACTA prescribe both "imprisonment and monetary fines sufficiently high to provide a deterrent to future" infringements. Note, however, that TPP also adds that such penalties should be "consistent with a policy of removing the infringer's monetary incentive." TPP omits ACTA's safeguard that such penalties shall be consistent with "the level of penalties applied for crimes of a corresponding gravity." Furthermore, TPP requires party members to establish policies or guidelines to "encourage judicial authorities to [actually] impose those penalties." TRIPS Art. 61 requires either monetary penalties or imprisonment, but not both.

\section{B. Arts. 15.5(b), Seizures}

TPP Art. 15.5(b), modeled on ACTA Art. 25.1,167 requires that judicial authorities

${ }^{165}$ See KORUS Art. 18.10.27(a) (same); see also ACTA Art. 24 (stating that "[f]or offences specified in paragraphs 1, 2, and 4 of Article 23 (Criminal Offences), each Party shall provide penalties that include imprisonment as well as monetary fines sufficiently high to provide a deterrent to future acts of infringement, consistently with the level of penalties applied for crimes of a corresponding gravity.")

${ }^{166}$ See Jodie Griffin, Inconsistencies Between the Trans-Pacific Partnership (TPP) Agreement and US Law, Public Knowledge, www.publicknowledge.org/files/TPP\%20Analysis.pdf

${ }^{167}$ ACTA Art. 25.1 (providing that parties "shall provide that its competent authorities have the authority to order the seizure of suspected counterfeit trademark goods or pirated copyright goods, any related materials and implements used in the commission of the alleged offence, documentary evidence relevant to the alleged offence, and the assets derived from, or obtained directly or 
have the authority to order the seizure of "suspected" counterfeit or pirated goods and implements. The TPP proposal adds that "items that are subject to seizure pursuant to any such judicial order need not be individually identified so long as they fall within general categories specified in the order."

The duty to not require individual identification of property seized by government officials may implicate constitutional and human rights protections. The Fourth Amendment to the U.S. Constitution requires that search and seizure warrants "particularly" describe places to be searched and items to be seized.168 Similar guarantees against arbitrary searches and seizures of property may be implicated in other TPP countries.

\section{C. $15.5(d)(i)$ - Seizure, Forfeiture, and Destruction}

TPP Art. 15.5(d)(i) would require the forfeiture and destruction of all counterfeit or pirated goods. This provision is similar to similar to ACTA Art. 25.3,169 except that ACTA requires the forfeiture OR destruction of such goods. While both TPP and ACTA allow for an exception, TPP does not adopt the ACTA exception that allows goods to be "disposed of outside the channels of commerce" rather than destroyed. The lack of this exception may prevent, for example, the donation of the infringing goods to charity.

\section{Special measures Relating to Enforcement in the Digital EnVIRONMENT}

\section{A. Art. 16.3 - Internet Service Provider Liability}

TPP contains two sets of standards that encourage internet service providers to police the content of the users of their networks.

First, Art. 16.3(a) requires parties to provide "legal incentives for service providers to cooperate with copyright owners in deterring the unauthorized storage and transmission of copyrighted materials." ACTA requires only that governments

indirectly through, the alleged infringing activity.").

168 See Jodie Griffin, Inconsistencies Between the Trans-Pacific Partnership (TPP) Agreement and US Law, Public Knowledge, www.publicknowledge.org/files/TPP\%20Analysis.pdf

${ }^{169}$ ACTA Art. 25.3 ("[w]ith respect to the offences specified in paragraphs 1, 2, 3, and 4 of Article 23 (Criminal Offences) for which a Party provides criminal procedures and penalties, that Party shall provide that its competent authorities have the authority to order the forfeiture or destruction of all counterfeit trademark goods or pirated copyright goods. In cases where counterfeit trademark goods and pirated copyright goods are not destroyed, the competent authorities shall ensure that, except in exceptional circumstances, such goods shall be disposed of outside the channels of commerce in such a manner as to avoid causing any harm to the right holder. Each Party shall ensure that the forfeiture or destruction of such goods shall occur without compensation of any sort to the infringer."). 
"endeavor to promote cooperative efforts within the business community."170 Providing legal incentives for ISPs to police the internet is a complex task for which negotiation of standards in secretive international processes is completely inappropriate. Intermediaries' interests are not perfectly aligned with user interests. Providing legal incentives for intermediaries to police networks may lead to the censoring of content, including legitimate content, choking innovative technology built on their platforms, surveillance of users, and threats to privacy and freedom of expression. ${ }^{171}$ The kind of private ordering of copyright enforcement represented by the TPP text has been a method of choice in the U.S., as evidenced by a recent Memorandum of Understanding between intermediaries and contentowners, encouraged by the U.S. Copyright Czar. ${ }^{172}$ Language about encouraging such cooperation should be viewed in light of these developments, which leave businesses unaccountable to users, and users without normal expectations of due process protected through court proceedings.

Second, the TPP proposal introduces a series of liability safeguards for ISPs, and in so doing may promote the extension of secondary liability to ISPs. Intermediary liability is not universally recognized. USTR has recognized that creating limitations on liability encourages countries to adopt intermediary liability in the first instance. ${ }^{173}$

It can be argued that TPP Art. 16.3 mandates a system of ISP liability that "goes beyond DMCA standards" and U.S. case law. ${ }^{174}$ For example, TPP Art. 16.3(b)(xi) requires ISPs to identify Internet users suspected of infringement, where U.S. courts have found that ISPs are not subject to identification subpoenas. TPP Art. 16.3(b)(xi) lacks ACTA Art. 27.4's requirements that (i) there be a sufficient claim of infringement, (ii) the information be sought for the purpose of protecting or enforcing a copyright, and (iii) the procedures shall be implemented in a manner that avoids the creation of barriers to legitimate activity. The TPP Art. 16.3(b)(vii) also fails to include the DMCA's second privacy provision, that intermediaries may

${ }^{170}$ Compare TPP Art. 16.3(a) with ACTA Art. 27.3.

${ }^{171}$ Margot Kaminski, Plurilateral Trade Agreements Lack Protections for Users, Intermediaries, http://infojustice.org/archives/5951

172 See David Kravets, U.S. Copyright Czar Cozied Up to Content Industry, E-Mails Show, WIRED (Oct. 14, 2011), available at http://www.wired.com/threatlevel/2011/10/copyright-czar-cozies-up/\#more31071. See generally Annemarie Bridy, Graduated Response and the Turn to Private Ordering in Online Copyright Enforcement, 89 OR. L. REV. 81, 2010) (analyzing private ordering copyright enforcement and graduated response).

${ }^{173}$ See U.S.-Peru FTA fn 28 (agreement language explicitly tempering that conclusion) http://www.ustr.gov/webfm_send/1031.

${ }^{174}$ The Complete Feb 10, 2011 text of the US proposal for the TPP IPR chapter, KNOWLEDGE ECOLOGY INTERNATIONAL, [hereinafter KEI] available at http://keionline.org/node/1091. 
not access material contrary to law. ${ }^{175}$ ACTA Art. 27.2 similarly requires that any system of digital enforcement be consistent with that Party's law, and preserve fundamental principles such as freedom of expression, fair process, and privacy. There are other examples of discrepancies between the TPP and DMCA, as well. ${ }^{176}$

The TPP contains a U.S. side-letter outlining notice-and-takedown, which was rejected by Chile in signing its free trade agreement. That rejection allows significantly more flexibility in implementation of any notice-and-takedown regime.

Finally, TPP contains language in Art. 15.4 criminalizing "aiding and abetting" copyright infringement, that is likely intended to apply to online intermediaries. In ACTA, the provision on aiding and abetting in Art. 23.4 was directly followed by a provision requiring liability for legal persons-that is, companies-in Art. 23.5. Criminal aiding and abetting has not appeared in other free trade agreements, and when read in light of ACTA's language on legal persons, may very well be intended to apply to intermediaries. In the U.S., the Bureau of Immigrations and Customs Enforcement (ICE) has been seizing domain names based in part on this theory of criminal liability. ${ }^{177}$ Criminal liability for intermediaries could threaten even those intermediaries that comply with safe harbors, as criminal and civil systems are distinct.

\section{Transparency and Procedural Fairness for Healthcare TeChnologies}

Among the U.S. Trans Pacific Partnership (TPP) proposals leaked during the Peru round was a proposed chapter on "Transparency and Procedural Fairness for Healthcare Technologies."

\section{A. X.1: Agreed Principles.}

The agreed principles are verbatim restatements from the KORUS agreement. As in KORUS, they understate the role and importance of promoting affordability through pharmaceutical reimbursement policies. The provisions mainly discuss the promotion of "access" and "availability" of pharmaceuticals. The concept of affordability is mentioned only once. USTR's recent white paper on TPP and medicines also defines "access" without reference to affordability concerns. One of

\footnotetext{
175 Digital Millennium Copyright Act, 17 U.S.C. § 512(m)(2).

176 Margot Kaminski, Margot Kaminski: Plurilateral Trade Agreements Lack Protections for Users, Intermediaries, INFOJUSTICE.ORG (Oct. 27, 2011), http://infojustice.org/archives/5951, originally posted on http://www.ip-watch.org/weblog/2011/10/27/plurilateral-trade-agreements-lackprotections-for-users-intermediaries/

177 See David Robinson, Following the Money: A Better Way Forward on the PROTECT IP Act, Information Society Project Working Paper Series, No. 1, http://www.law.yale.edu/intellectuallife/6564.htm.
} 
the key purposes of drug reimbursement programs must be to promote affordable access to pharmaceuticals, not mere availability of the products themselves. This concern applies throughout the proposal.

\section{B. X.2: Transparency Related to Healthcare Technologies.}

The provision creates a vague requirement that "all measures" related to pharmaceutical reimbursement be administered in an "objective" manner. This concept of "objective" administration of the law is not a current U.S. legal requirement and is not defined in the agreement. What it means in this context is unclear, which may open opportunities for pharmaceutical companies to attempt to define it through litigation. What is a non-objective administration of the law? Would the choosing of drugs for a formulary based on a multitude of factors including price and availability decisions pass the test?

\section{X.3: Procedural Fairness Related to Healthcare Technologies.}

This is the core section forcing countries to use formal rulemaking processes rather than market negotiations to determine reimbursement prices. International law should not determine this important policy choice. Countries must be free to use reimbursement programs as a player in the market rather than as its regulator.

\section{1. $\quad X .3(a)$}

The term "reasonable period" has no definition in the agreement or in U.S. or international law. It invites litigation.

\section{2. $\quad x .3(b)$}

The requirement to disclose all methodologies used to negotiate drug prices is one of many rules forcing the government to operate as a price regulator rather than market participant. Private companies do not disclose such information to their suppliers.

\section{3. $\quad x .3(c)$}

The requirement to give notice and comment opportunities during reimbursement decisions prevents health authorities from using negotiation rather regulation to set drug prices. Private entities do not invite public comments on their negotiations with suppliers.

\section{4. $\quad x .3(d)$}

This is one of the most worrisome provisions in the text. The provision has two parts:

- The first part encourages countries to abandon any economy of scale benefits from pooled purchasing through government and instead reimburse 
pharmaceutical companies at rates "consisting of competitive market-driven prices in the Party's territory." (The restriction to "in the Party's territory" was not included in previous agreements and is designed to restrict countries from the common practice of using international reference prices to determine reasonable reimbursement rates.) This rule is not followed in the U.S. Medicaid programs receive discounts of up to $50 \%$ off the list price for pharmaceuticals due to their increased purchasing power. The provision is also practically unworkable since other large private purchasers in the market will not be under any obligation to disclose their "market-driven" prices.

- The second part of this section, read with paragraph (i), provides that if countries do not set reimbursement prices at the "competitive marketdriven" price, then they must provide companies with appeals of whether reimbursement prices "appropriately recognize the value" of patents. There is no objective measure of the "value" of a patent. Economists normally define value as a function of market price. But in a monopoly market for an essential good, particularly in countries with high income inequality, this market price will be excessively high absent government regulation. It is impossible to know how this provision would be implemented. It invites litigation and promotes uncertainty.

\section{5. $\quad x .3(e)$}

This provision mandates that countries allow companies to "apply for an increased amount" of reimbursement based on evidence of "superior safety, efficacy or quality." This provision is potentially beneficial in embracing the idea that prices should be set based on efficacy rather than market value. Nonetheless, affordability concerns must also be an integral part of reimbursement decisions, but are not mentioned.

\section{6. $\quad x .3(f)$}

This provision mandates that governments allow companies to "apply" for reimbursements for additional medical indications for products. The provision has no requirement that the additional indications applied for first be approved by the government's medical registration authorities. It rather suggests that the safety and efficacy information would be submitted directly to the reimbursement entity, side stepping regulatory authorities.

\section{7. $\quad x .3(g, h, i)$}

These provisions require that governments provide written reasons for every decision $[(\mathrm{g})$ and $(\mathrm{h})]$ and then provide an "independent appeal" of any 
reimbursement decision (i), presumably based on the substantive restrictions on reimbursement programs defined in X.2(d). These provisions will likely increase pharmaceutical company negotiating power to exact higher prices from governments through litigation threats.

\section{8. $\quad X .3(k)$}

This provision requires that all members of reimbursement committees be made public, presumably to enable targeted lobbying from pharmaceutical companies. Such lobbying can be detrimental to public decision making, especially when linked to unethical gift giving that has plagued pharmaceutical marketing in the U.S. and elsewhere.

\section{X.4: Dissemination of Information to Health Professionals and Consumers}

This provision attempts to set drug marketing policy through trade agreements. It would mandate that countries allow certain kinds of direct-to-consumer and direct-to-physician marketing efforts over the internet. This is a subject currently subject to regulatory investigations in the U.S. and would be contrary to the drug marketing laws of many countries. The provision would appear to make illegal a proposal by Representative Waxman that companies not be allowed to engage in certain kinds of direct to consumer promotion in the first three years of a drug's time on the market.

\section{E. X.5: Ethical business practices [no text]}

As in other areas of the TPP, provisions protecting corporate concerns are well developed and those potentially protecting consumers are absent. This section should consider standards that would ban gift giving and other pecuniary relationships between pharmaceutical companies and prescribers or government health officials. It should ban off-label marketing of drugs. It should mandate private and public rights of action against fraudulent and misleading marketing practices.

\section{F. X.6: Cooperation}

As in the agreed principles, this provision appears tailored to promote a conception of "availability" that does not include affordability. The key concern of countries in the region, and in particular the U.S., should be on sharing information on how best to ensure the affordability of medicines in the context of the ongoing economic crisis.

\section{G. X.7: Definitions}

Few of the key terms in the agreement are defined, including "access," "value," "reimbursement" and "health care programs" as applied to the scope of coverage, "transparent," "verifiable," "objective," "competitive-market derived," "independent" 
as related to "appeal or review."

\section{H. X.7 fn 2. (U.S. carve out?)}

In previous agreements with the U.S. including pharmaceutical chapters, the U.S. has claimed that they have no application to programs in the U.S. This in part because the largest federal drug reimbursement program in the U.S. - included in the Medicaid program - is administered by state governments (although created by federal statute). The Australian and Korean agreements were crafted to apply to the "central" level of government. The KORUS agreement included a footnote stating: "For greater certainty, Medicaid is a regional level of government health care program in the United States, not a central level of government program."

The Medicaid carve out in the Korea FTA has been criticized in the U.S. for potentially leaving vulnerable other U.S. programs that control prices on drugs in government programs in similar ways as the Korean and Australian governments, including through Medicare and the so-called 340b program for community hospitals. TPP removes this footnote form the proposed text and substitutes a bracketed place holder for clarification of the scope of application. This should be concerning to US health advocates and officials. A letter from several senior members of the US Congress, released during the Chicago round of negotiations, instructed that "TPP should not undermine either U.S. or other member countries' current or prospective, non-discriminatory drug reimbursement policies and programs (e.g. Medicare, Medicaid, the VA, and other programs)."

Indeed, there are strong voices in the U.S. in opposition to any restrictions on reimbursement programs within TPP, even if they do effectively carve out all existing U.S. programs. Vermont Governor Peter Shumlin wrote President Obama with respect to a possible TPP pharmaceutical chapter:

Even if a chapter was proposed that did include a Medicaid carve-out, state leaders believe it is inappropriate for U.S. trade policy to advance restrictions on pharmaceutical pricing programs that U.S. programs do not meet but for technical carve outs. ${ }^{178}$

\section{CONCLUSION}

The U.S. proposals, if adopted, would create the highest intellectual property protection and enforcement standards in any free trade agreement to date. If adopted, the TPP would predictably lead to higher prices and decreased access to a broad range of consumer products in many TPP member countries, from medicines to textbooks to information on the internet, with little or no benefit to any TPP

178 Letter from Peter Shumlin, Governor, Vt. to President Barack Obama (June 1, 2011), available at http://www.forumdemocracy.net/downloads/Letter\%20from\%20VT\%20Gov.\%20Shumlin\%20to\%20Presi dent\%20Obama\%20-\%20June\%201,\%202011.pdf. 
member in the form of increased innovation, creativity or local economic activity. Despite the broad ranging impact so the agreement on the public, it is being negotiated under conditions of secrecy that are inimical to the construction of good public policy. Negotiating legislative minimum standards agreements through processes where the public affected by those norms cannot observe the standards being discussed, much less participate in their creation, is an affront to democracy and the principles of good government. We advise that all members of the TPP negotiation reject the maximalist standards of the U.S. proposal and move the debate of global intellectual property norms to an open and transparent process where a full range of stakeholders can observe and participate. 